\title{
Probing Guyana's Provenance Of Underdevelopment per Doctrine of Discovery, Degenerated Democracy \& Kleptocracy
}

\author{
Nazim Baluch
}

\begin{abstract}
The article, while critically examining the provenance of Guyana's "underdevelopment", scrutinizes effects of "Doctrine of Discovery", and construes that "maraud" befittingly describes the purpose of European discovery voyages to Americas and the Caribbean: the "genocides"; "institutionalized-injustice"; "Human Zoos"; and "systematic atrocities" perpetuated by the European monarchies ravaged Americas, Caribbean, and African nations - inflicting irreversible devastation that persists to this day. The British, questing for Guyana's resources, setup bare infrastructure and institutions to facilitate "looting" while keeping it "underdeveloped" and its population in "abject poverty". They were, absolutely, not interested in developing Guyana. However, US \& UK continue meddling in Guyanese affairs: bankrolling "Democracy Degeneration"; enabling "Kleptocracy" that has been draining Guyana for the last five decades; and, now, drooling over potential oil money. The article recommends that Guyana is ravenous for legitimate, antidotal, "constitutional reforms" guaranteeing a decentralised, pragmatic, governing model that is: participatory; transparent; accountable; responsive; equitable; and inclusive. To abrogate "Colonial Dehumanisation Effects", Guyana needs to restore the indigenous peoples "Human Dignity", "Identity" and "Rights"; rid Guyana of the antiquated, repressive colonial institutions; and reform the archaic education system. "Analog Generation" has to let go; $\mathbf{2 1}^{\text {st }}$ century belongs to "netizens-digital generation", they must fully participate and play a decisive role in Guyana's politics and development. Guyanese must use technology to "Reinvent Democracy" and ensure that; it is neither "hacked" nor "hijacked", "Global Democracy" does not undermine "National Democracy", and "Political Clientelism" is eradicated for good.
\end{abstract}

Keywords: Political Clientelism, Doctrine of Discovery, Degenerated Democracy, Kleptocracy, netizens, underdevelopment.

\section{PRELUDE}

To understand underdevelopment and to put it into perspective, we need to define its antonym - development. Through the years, professionals and researchers developed a number of definitions and emphases for the term "development." Amartya Sen, for example, developed the "capability approach," which defined development as a tool enabling people to reach the highest level of their ability, through granting freedom of action, i.e., freedom of economic, social and family actions, etc. This approach became a basis for the measurement of development by the Human Development Index (HDI). In contrast, professionals like Jeffrey Sachs and Paul Collier focused on mechanisms that prevent or oppress development causing abject poverty. Both, Sacks and Collier, promote concept of sustainable development [1, 2]. MaxNeef, emphasized that: development is about people and not about objects; growth is not the same as development; and development does not necessarily require growth - and the fundamental value to sustain a new economy should be that no economic interest, under no circumstance, can be above the reverence of life [3]. Fioramonti, advances this concept arguing that in order to promote inclusive sustainable development, world must extricate itself from the GDP (Gross Domestic Product) based development model of economy and accost wellbeing economy that measures development through HDI, LCI (living conditions index), MPI (Multidimensional Poverty Index), LPI (Legatum Prosperity Index), and GGEI (Global Green Economy Index); GDP in fact has wangled into Gross Domestic Problem [4]. So, with this 
perceptive, underdevelopment is the antithesis of development; subjugation, injustice, forlorn poverty, malnutrition, and poorer public health and education systems. So, for identifying the root causes of "Underdevelopment" we need to go back in history, real history, not the fake-one [5], to discern the five centuries of injustice endured by Americas and the Caribbean.

\section{DOCTRINE OF DISCOVERY - 500 YEARS OF INJUSTICE}

Spiritual malaise and social turmoil were rife in $15^{\text {th }}$ century Europe. Epidemic diseases and famine raged. Death was omnipresent. War was widespread and institutions of authority like the Church were venal and corrupt. The 'discovery' of America offered the possibility of a new beginning for Europe. Unfortunately, the invading powers chose to solve their problems at the expense of the new land and the native Americans who lived there ${ }^{[6]}$.

When Columbus sailed west across the Sea of Darkness in 1492 - with the express understanding that he was authorized to "take possession" of any lands he "discovered" that were "not under the dominion of any Christian rulers" - he and the Spanish sovereigns of Aragon and Castile were following an already well-established tradition of "discovery" and conquest. Indeed, after Columbus returned to Europe, Pope Alexander VI issued a papal document, the bull Inter Cetera of May 3rd, 1493, "granting" to Spain - at the request of Ferdinand and Isabella - the right to conquer the lands which Columbus had already found, as well as any lands which Spain might "discover" in the future. In the Inter Cetera document, Pope Alexander stated his desire that the "discovered" people be "subjugated and brought to the faith itself." By this means, said the pope, the "Christian Empire" would be propagated. When Portugal protested this concession to Spain, Pope Alexander stipulated in a subsequent bull - issued May $4^{\text {th }}, 1493$ - that Spain must not attempt to establish its dominion over lands which had already "come into the possession of any Christian lords." Then, to placate the two rival monarchs, the pope drew a line of demarcation between the two poles, giving Spain rights of conquest and dominion over one side of the globe, and Portugal over the other. During this quin-centennial of Columbus' journey to the Americas, it is important to recognize that the grim acts of genocide and conquest committed by Columbus and his men against the peaceful Native people of the Caribbean were sanctioned by the abovementioned documents of the Catholic Church. Indeed, these papal documents were frequently used by Christian European conquerors in the Americas and the Caribbean to justify an incredibly brutal system of colonization - which dehumanized the indigenous people by regarding their territories as being "inhabited only by brute animals [7]."

The lesson to be learned is that the Papal Bull Dum Diversas of June $18^{\text {th }}, 1452$ \& Sep $26^{\text {th }}, 1493$ and Inter Cetera bull of May $3^{\text {rd }}, 1493$ are clear examples of how the "Christian Powers," or "different States of Christendom," viewed indigenous peoples as "the lawful spoil and prey of their civilized conquerors." In fact, the Christian "Law of Nations" asserted that Christian nations had a divine right, based on the Bible, to claim absolute title to and ultimate authority over any newly "discovered" Non-Christian inhabitants and their lands. Over the next several centuries, these beliefs gave rise to the Doctrine of Discovery used by Spain, Portugal, England, France, Belgium, Netherlands, Italy, and Germany - all Christian nations. Over 500-years of "Institutionalized-Injustice \& Systematic Atrocities" perpetuated by these monarchies have ravaged Americas, Caribbean, and African nations; inflicting irreversible devastation that persists to this day. The Doctrine of Discovery is still being used by countries throughout the Americas to deny the rights of indigenous peoples, and to eternalize colonization throughout the Americas. The Inter Cetera bull of May 3rd, 1493 has not been formally revoked till today by the Church; So, to begin to bring that system of colonization to an end, and to move away from a cultural and spiritual tradition of subjugation and genocide, of indigenous peoples of the 
Western Hemisphere and the peoples of Africa. It is worthy to note that in 1823, the Christian Doctrine of Discovery was quietly adopted into U.S. law by the Supreme Court in the celebrated case, Johnson v. McIntosh [8]; and is being used to justify US Military and Clandestine (Overt \& Covert) Operations domestically and in foreign lands [9].

\section{Slavery and Human Zoos}

Centuries of institutionalized injustice and racism was invalidly based on the presumed racial superiority of European Christian peoples and was used to dehumanize, exploit and subjugate Indigenous and African Peoples and dispossess them of their most basic rights. This was the very foundation of genocide. Such ideology led to practices that continue through modern-day laws and policies. It is no-coincidence that racism is deeply embedded in our culture. Slavery of African peoples, ethnic cleansing of Latin America \& Caribbean (LAC) Natives, and Colonialist Imperialism Atrocities are seeds that intertwine to create racism that still has impacts today. One example of the sad human history of racism - of colonizers seeing themselves as superior to others - is the long history of "Human Zoos" that featured Africans and conquered indigenous peoples, putting them on display in much the same way as animals. People would be kidnapped and brought to be exhibited in human zoos. It was not uncommon for these people to die quickly, even within a year of their captivity. Only decades before, in the late 1800's, Europe had been filled with, human zoos, in cities like Paris, Hamburg, Antwerp, Barcelona, London, Milan, and Warsaw. New York too, saw these popular exhibits continue into the $20^{\text {th }}$ century. There was an average of 200,000 to 300,000 visitors who attended each exhibition in each city. Carl Hagenbeck, of Germany ran exhibits of what he called, "purely natural," populations, usually East Asian Islanders, but in 1876, he also sent a collaborator to Sudan to bring back, "wild beasts and Nubians." The traveling Nubian exhibit was a huge success in cities like Paris, London, and Berlin. In 1906, the amateur anthropologist Madison Grant, who was the head of the New York Zoological Society, put a Congolese pygmy Ota Benga, on display at the Bronx Zoo in New York City. The display was in the primate exhibit, and Ota was often made to carry around chimpanzees and other apes. Eugenicist and zoo director William Hornaday labeled Ota, "The Missing Link." The public flocked to see the display. This history is long and deep and continued into the 1950s [10]. The slave trade, beginning in the mid to late 17th century, became so pervasive throughout Africa that it drove out almost all other commodities in African trade. However, slavery was eventually abolished in 1863, although slaves were only released after a ten-year transitory period in 1873 . This spurred the immigration of indentured labourers from British India, after a treaty to that effect had been signed between the Netherlands and the United Kingdom in 1870.

\section{Colonialism in Guyana}

The recorded history of Guyana can be dated back to 1499, when Alonso de Ojeda's first expedition arrived from Spain at the Essequibo River. The history of Guyana has been shaped by the participation of many national and ethnic groups, as well as the colonial policies of the Spanish, French, Dutch, and British. Although Guyana was claimed by the Spanish since 1502 who sent periodic patrols through the region; Spain controlled Province of Venezuela through its permanent settlement at Cumana and later at Caracas. The Dutch arrived in Guyana in 1616 and gained control over the region in the early $17^{\text {th }}$ century. Dutch sovereignty was officially recognized with the signing of the Treaty of Munster in 1648. In 1621 the government of the Netherlands gave the newly formed Dutch West India Company complete control over the trading post on the Essequibo. This Dutch commercial concern administered the colony, known as Essequibo, for more than 170 years. The company established a second colony, on the Berbice River southeast of Essequibo, in 1627. Demerara, situated between Essequibo and Berbice, was settled in 1741 and emerged in 1773 as a separate colony under direct control of the Dutch West India Company. The name Netherland means lowlands. The Dutch and their 
ancestors have been working to hold back and reclaim land from the North Sea for over 2000 years. The physical and institutional polder culture is indeed a crucial aspect of the Dutch national identity; this is what they brought to their colonies of Berbice and Demerara \& Essequibo - polder agriculture. The growing importance of agriculture was indicated by the export of 15,000 kilograms of tobacco from Essequibo in 1623. But as the agricultural productivity of the Dutch colonies increased, a labor shortage emerged. The indigenous populations were poorly adapted for work on plantations, and many people died from diseases introduced by the Europeans. The Dutch West India Company turned to the importation of enslaved Africans, who rapidly became a key element in the colonial economy. Most of AfroGuyanese inhabitants are of Sub-Saharan West African descent [11].

\section{British Control of Guyana}

Eager to attract more settlers, in 1746 the Dutch authorities opened the area near the Demerara River to British immigrants. British plantation owners in the Lesser Antilles had been plagued by poor soil and erosion, and many were lured to the Dutch colonies by richer soils and the promise of landownership. The influx of British citizens was so great that by 1760 the English constituted a majority of the European population of Demerara. By 1786 the internal affairs of this Dutch colony were effectively under British control, though two-thirds of the plantation owners were still Dutch.

As economic growth accelerated in Demerara and Essequibo, strains began to appear in the relations between the planters and the Dutch West India Company. In 1781 a war broke out between the Netherlands and Britain, which resulted in the British occupation of Berbice, Essequibo, and Demerara. Some months later, France, allied with the Netherlands, seized control of the colonies. The French governed for two years, during which they constructed a new town, Longchamps, in 1781, at the mouth of the Demerara River. When the Dutch regained power in 1784, they moved their colonial capital to Longchamps, which they renamed Stabroek. The capital was in 1812 renamed Georgetown by the British. At the London Convention of 1814, both colonies were formally ceded to Britain. In 1831, Berbice and the United Colony of Demerara \& Essequibo were unified as British Guiana and remain under British control until independence in 1966.

British Guiana became a Crown colony in 1928, and in 1953 it was granted home rule. In 1950, Cheddi Jagan (Indo-Guyanese), and Forbes Burnham (Afro-Guyanese), created the colony's first political party, the Progressive People's Party (PPP), which was dedicated to gaining the colony's independence. In the 1953 elections, Cheddi Jagan was elected chief minister. The British, however, alarmed by Jagan's Marxist views, suspended the constitution and government within months and installed an interim government. In 1955, the PPP split, with Burnham breaking off to create the People's National Congress (PNC). The leftist Jagan of the PPP and the more moderate Burnham of the PNC were to dominate Guyana politics for decades to come. In 1961, Britain granted the colony autonomy, and Jagan became prime minister (1961-1964). Strikes and rioting weakened Jagan's rule, much of it believed to be the result of covert CIA operations [12]. In 1964, Burnham succeeded Jagan as prime minister, a position he retained after the country gained full independence on May 26, 1966. The transfer of power in British Guiana between 1961 and 1964 illustrates Louis and Robinson's claim that British imperial disengagement was managed by the Anglo-American coalition. It shows how the two powers constantly re-negotiated the terms of their relationship in various parts of the world in order to maintain their strategic partnership. And it shows how British disengagement created the conditions for US control. In effect, the transfer of power in British Guiana was not simply the accession to office in an independent country by the nationalist elite; it also transferred 
control of the country's political system and economic and foreign policy to the United States [13]. With independence, the country returned to its traditional name, Guyana. However, after the independence the extraction and looting of resources of the colonies continued - loot was handled by the banks; colonial powers had planted their cronies as the new leaders whom Fanon, calls "colonized intellectuals" - these kleptocrats have been loyal to their masters eversince [14].

\section{US Hegemony since World War II}

Though large-scale geopolitical changes are afoot and we are witnessing the beginning of the end of unipolar world order, dominated by the United States. The idea of American hegemony is as old as Benjamin Franklin, but has its practical roots in WWII since The US emerged from that war as the dominant economic, political and technological power. Hegemonic geopolitics drives American foreign policy since. For over sixty-five years, the US war machine has been on auto-pilot. Since WWII we have been conditioned to believe that America's motives in 'exporting' democracy are honorable, even noble. In his startling and provocative book, America's Deadliest Export: Democracy, William Blum argues that nothing could be further from the truth. Principally, one must come to the realization that the US strives to dominate the world, for which end it is prepared to use any means necessary. Once one understands that, much of the apparent confusion, contradiction, and ambiguity surrounding Washington's policies fades away. Moreover, unless this fallacy is unlearned, and until people understand fully the worldwide suffering American policy has caused, we will never be able to stop the monster. To express this striving for dominance numerically - until 2013 account, one can consider that since the end of WWII the US has; endeavored to overthrow more than 50 foreign governments, most of which were democratically elected; grossly interfered in democratic elections in at least 30 countries; attempted to assassinate more than 50 foreign leaders; dropped bombs on the people of more than 30 countries; attempted to suppress a populist or nationalist movement in 20 countries. Despite the extensive documentation of the crimes of US foreign policy, because of the very breadth of American interventions and the time period of sixty-eight years it's much more difficult for the world to fully grasp what the US has done. Since 1945, the US has carried out one or more of the above-listed actions, on one or more occasions, in seventy-one countries (more than one-third of the countries of the world), in the process of which the US has ended the lives of several million people, condemned many millions more to a life of agony and despair, and has been responsible for the torture of countless thousands [15,16].

\section{Dehumanizing Effects of Colonialism}

Maraud, befittingly describes the purpose of European discovery voyages to Americas and the Caribbean. Under various theological and legal doctrines formulated during and after the Crusades, non-Christians were considered enemies of the Catholic faith and, as such, less than human. Accordingly, in the bull of June 18 ${ }^{\text {th }}, 1452$, and the subsequent bull 'Romanus Pontifex' of January $5^{\text {th }}, 1455$ Pope Nicholas directed King Alfonso to "capture, vanquish, and subdue the Saracens, Pagans, and other enemies of Christ," to "put them into perpetual slavery," and "to take all their possessions and property." Acting on this papal privilege, and papal bulls of 1493 and Inter Cetera bull of May $4^{\text {th }}, 1493$ - all Christian nations, pillaged and plundered Americas and the Caribbean for next five centuries. It would be duplicitous to consider that the European looters were, even remotely, interested in the development of the peoples of Americas and the Caribbean [17]. This is the naked truth, every thing else is fake-history [18]. Colonialism conquered nations - its population, and exploiting them, while forcing its own language and cultural values upon its people. The British, like all colonial powers, were in their quest for Guyana's resources. They setup bare minimum infrastructure and administrative institutions that facilitated the extractive industries work and established extractive institutional 
framework to facilitate the plunder while keeping the population under check through divide and rule politics. This is what the British did - in plain words, they looted, pillaged and plundered Guyana while keeping its population in abject poverty. Development of the people of Guyana was the last thing on their minds [19].

In fact, historically, Britain owes much of its wealth and power to the exploitation of the African continent. In the Channel 4 documentary The Empire Pays Back [20], Robert Beckford estimates Britain's debt to Africans in the continent and diaspora to be in the vicinity of 7.5 trillion pounds. Without Africa and its Caribbean plantation extensions, the modern world as we know it, would not exist. Britain financed its Industrial Revolution through profits from slavery and it found markets for its commodities in its African colonies. Today, exploitation is still in full swing, albeit through more subtle mechanisms. After decolonisation, plunder of other nations is being sustained by the banks. Europe no longer loots Africa directly, by kidnapping its people or stealing its gold, but by enlisting the support of local elites -kleptocrats, and locking its people into vicious economic structures which robs the continent of billions every year [21]. A new World Bank report, The Changing Wealth of Nations 2018, offers evidence of how much poorer Africa is becoming thanks to rampant minerals, oil and gas extraction. Yet Bank policies and practices remain oriented to enforcing foreign loan repayments and transnational corporate (TNC) profit repatriation, thus maintaining the looting. Africa's smash-and-grab 'development policies' aiming to attract Foreign Direct Investment have, even the Bank suggests, now become counter-productive.

Frantz Fanon in his book "The Wretched of the Earth (1961)", provides a psychiatric and psychologic analysis of the dehumanizing effects of colonization upon the individual and the nation, and discusses the broader social, cultural, and political implications inherent to establishing a social movement for the decolonization of a person and of a people. Through critiques of nationalism and of imperialism, Fanon presents a discussion of personal and societal mental health, a discussion of how the use of language (vocabulary) is applied to the establishment of imperialist identities, such as colonizer and colonized, to teach and psychologically mold the native and the colonist into their respective roles as slave and master. Fanon characterizes the assessment of the native population by the settler class as dehumanizing. The settlers literally do not see the natives as members of the same species. The natives are incapable of ethics and thereby are the embodiment of absolute evil as opposed to the Christian settlers who are forces of good [22]. One of the temporary consequences of colonization that Fanon talks about is division of the native into three groups. The first is the native worker who is valued by the settler for their labor. The second group is what he calls the "colonized intellectual". These are, by western standards, the more educated members of the native group who are in many ways recruited by the settler to be spokespeople for their views - kind of sheepdogs. The settlers had "implanted in the minds of the colonized intellectual that the essential qualities remain eternal in spite of the blunders men may make: the essential qualities of the West, of course"; these intellectuals were "ready to defend the Graeco-Latin pedestal" against all foes, settler or native. The third group described by Fanon are the lumpenproletariat. This group is described as the poorest class; those who are outside of the system because they have so little ${ }^{[23]}$.

To fight enfeebled decolonization by the tentativeness of its colonized intellectual leaders "the newly independent Third World countries are urged not to emulate the decadent societies of the West (or East) in the Post-independence era, but to chart a new path in defining human and international relationship" [24]. For Fanon, national culture is then intimately tied to the struggle for the nation itself, the act of living and engaging with the present reality that gives 
birth to the range of cultural productions. Concluding, Fanon is careful to point out that building a national culture is not an end to itself, but a 'stage' towards a larger international solidarity. The struggle for national culture induces a break from the inferior status that was imposed on the nation by the process of colonization, which in turn produces a 'national consciousness'. This national consciousness, born of struggle undertaken by the people, represents the highest form of national culture, according to Fanon. Through this process, the liberated nation emerges as an equal player on the international stage, where an international consciousness can discover and advance a set of universalizing values. However, in case of Guyana it did not happen. Instead the "Colonized Intellectual" group took over the reigns of governance of this new nation and, heeding to the advice of their colonial masters, kept the colonial institutions of overdeveloped state operating. Nothing altered, only change of guards, and the looting continues and underdevelopment persists to this day [25].

\section{Abrogating Colonial Dehumanisation Effects}

To abrogate the effects of five centuries of dehumanisation of Indigenous Guyanese peoples, first and foremost, we have to bring them into the fold of Humanness - which has two distinct features; Identity and Community [26]. Within the paradigmatic framework of democracy: Human Dignity, Human Rights and Human Identity are embedded in the basic human quest for meaning - teleology [27]. Indigenous peoples have to redeem their "dignity", "Identity" and inherently experience "freedom, liberty and justice" - since long they have been marginalized and forced to live on handouts. Without a sense of identity, there can be no real struggle. Freedom is not an ideal located outside of a person; nor is it an idea which becomes myth. It is rather the indispensable condition for the quest for human completion. Education is the main point that brings about liberty in the lives of individuals, households and even nations. Freire, while rejecting the "banking" approach, advocates for a more world-mediated, mutual approach to education that considers people incomplete - this "authentic" approach to education must allow people to be aware of their incompleteness and strive to be more fully human. This attempt to use education as a means of consciously shaping the person and the society is called "conscientization". Freire, proposes "dialogics" as an instrument to free the colonized, through the use of cooperation, unity, organization and cultural synthesis overcoming problems in society to liberate human beings. He adapted the existential notion of "limit situation" to the developing world, seeing the constraints of underdevelopment as a limit situation on humanity but also as a possible frontier point for increasing (in overcoming) one's human stature [28, 29].

\section{DEGENERATED DEMOCRACY \& KLEPTOCRACY}

British imperialistic colonialism, far from being benign, in most cases undermined colonial democratisation and development through its focus on maintaining physical order and control and sustaining economic extraction through "Overdeveloped States". However, different colonies experienced distinct post-independence trajectories, depending upon the character of indigenous social cleavages, elite strategies, the formation of political parties and movements, and the ability of indigenous leaders to manipulate limited opportunity structures. In fact, transitions to democracy in the post-independence colonies were blocked by an entrenched history of autocracy. Political players who inherited the post-colonial states kept the extractive apparatus of divide and rule - to continue the loot and pillage of the state resources. In fact, the main purpose of the extractive state was to transfer as much of the resources of the colony to the colonizer, with the minimum amount of investment possible. Since these colonies were created with the intent to extract resources, colonial powers had no incentive to invest in institutions or infrastructure that was outside the scope of resource extraction activities. 
Thus, Europeans established authoritarian regimes in these colonies, which had no limits on state power [30]. Walter Rodney in his book "How Europe Undeveloped Africa", republished in 2018, wrote about the poverty, the colonialism left in the Third World that made it underdeveloped - everything was underdeveloped - economy, classes, infrastructure, education etc. [31]. However, Alavi, stated that while the economy and society were underdeveloped, the state was overdeveloped [32]. In the case of Guyana under Burnham, the overdeveloped state became a class in itself. In fact, after their independence, most British Colonies kept their state machinery and oppressive justice system in tact; primarily to help the new elites keep their power-base effective. These pre-colonial institutions were not designed to establish democratic rule. So! solving post-colonial problems with the help of pre-colonial institutions is preposterous. Guyana is an "assembly-independent" regime. Winner-Takes-All politics have not delivered inclusive development to Guyana since independence in 1966. The USAID Report (2016) [33] assessment found problems in all five elements of democracy, human rights, and governance - namely: Consensus; Inclusion; Competition and political accountability; Rule of law and human rights; and Government responsiveness and effectiveness. The most critical were in the areas of competition and political accountability and government responsiveness and effectiveness. For 2020 elections, Guyana is ravenous for legitimate, antidotal, constitutional reforms that can guarantee the desired outcome for satisfactory governance in all the five elements of democracy stated earlier.

The Guyanese have a shared political culture and the belief that democracy is the only legitimate form of government, but long-standing acrimony between the PPP/C and PNC/R makes achieving consensus on policies, committee appointments, and constitutional reform priorities difficult at the national level. However, social capital and the shared desire for change facilitate consensus building at the regional and local levels. Consociational Democracy is perhaps the most influential form of government available to third-world countries which have suffered from the setbacks of the openly competitive Anglo-American democratic variant part based on zero-sum context, winner-takes-all benefits. However, in practice, politicisation of ethnic and racial differences is considered a major impediment to the success of Consociational Democracy. Hence it is suggested that investing in basic human development is a consistently more reliable route to achieve stable democracy and good governance than constitutional design alone. The real problem lies in the depraved behaviour of politicians in power. No wonder the trust in politicians globally is lowest among all professions; Guyanese politicians scored the lowest on the level of trust - 16\% [34]. However, politicians' depraved behaviour is the "symptom" and not the root-cause. To bring "a fundamental change in the political philosophy of those who wield power" - we need to get to the root-causes and try rectifying them. To understand the politicians' depraved behaviour, we need to familiarise ourselves with the developments that have shaped democracy and its institutions particularly since the dissolution of USSR in December 1991.

\section{Democracy}

The word Democracy comes from demos, "common people" and kratos, "strength". Led by Cleisthenes, Athenians established what is generally held as the first democracy - 508-507 BC. The Classical Greek philosopher Plato, in his Book-VIII Republic (380 BC) [35], discusses five types of regimes; Aristocracy, Timocracy, Oligarchy, Democracy, and Tyranny. These five regimes progressively degenerate starting with Aristocracy at the top and Tyranny at the bottom. Note the concept of degeneration. Democracy nowadays is commonly conceived of in political theory in terms of equality of power among the relevant population. This conception of democracy is, however, known to be plagued with difficulties. In particular, democratic equality is typically associated with some use of the majority rule, and is thereby linked to the 
related conundrums: unleashed majorities may oppress minorities and crush basic liberal rights; majority cycles may lead to chaotic decisions. Such likely unfairness and inconsistency of majoritarian decisions question the status of democracy as a normative ideal and complicate the relationship between democracy and liberal theories of social justice. It is often considered that there is a tension between democracy and justice, in spite of the central role played by the value of equality in both. Contemporary Scholars propose to replace the principle of equality by a principle of proportionality.

\section{Democracy's Road to Tyranny}

Plato, in his Republic, tells us that tyranny arises, as a rule, from democracy. Pondering the question of "Who should rule," the democrat gives his answer: "the majority of politically equal citizens, either in person or through their representatives." In other words, equality and majority rule are the two fundamental principles of democracy. A democracy may be either liberal or illiberal. Regardless of who rules, government must be carried out in such a way that each person enjoys the greatest amount of freedom, compatible with the common good.

How could a democracy, even an initially liberal one, develop into a totalitarian tyranny? There are three avenues of approach, and in each case the evolution would be of an "organic" nature. The tyranny would evolve from the very character of even a liberal democracy because there is, from the beginning on, a worm in the apple: freedom and equality do not mix, they practically exclude each other. Equality doesn't exist in nature and therefore can be established only by force. He who wants geographic equality has to dynamite mountains and fill up the valleys. To get a hedge of even height one has to apply pruning shears. To achieve equal scholastic levels in a school one would have to pressure certain students into extra hard work while holding back others [36].

The first road to totalitarian tyranny (though by no means the most frequently used) is the overthrow by force of a liberal democracy through a revolutionary movement, as a rule a party advocating tyranny but unable to win the necessary support in free elections. The stage for such violence is set if the parties represent philosophies so different as to make dialogue and compromise impossible. The second avenue toward totalitarian tyranny is "free elections." It can happen that a totalitarian party with great popularity gains such momentum and so many votes that it becomes legally and democratically a country's master. Barbados Labour Party (BLP), won all 30 seats in the House of Assembly in 2018 elections - members are elected in single-member constituencies by first-past-the-post voting. Then there is the third way in which a democracy changes into a totalitarian tyranny, first foreseen by Alexis de Tocqueville [37]. He envisaged a democratic government in which nearly all human affairs would be regulated by a mild, "compassionate" but determined government under which the citizens would practice their pursuit of happiness as "timid animals," losing all initiative and freedom which he referred to as "democratic despotism." This process can be much more paralyzing than a mere personal dictatorship, military or otherwise, without an ideological and totalitarian character. The Franco and Salazar regimes and certain Latin American authoritarian governments, all mellowing with the years, are good examples [38].

Tocqueville, did not tell us just how the gradual change toward totalitarian servitude can come about. But 150 years ago, he could not exactly foresee that the parliamentary scene would produce two main types of parties: the Santa Claus parties, predominantly on the Left, and the Tighten-Your-Belt parties, more or less on the Right. The Santa Claus parties, with presents for the many, normally take from some people to give to others: they operate with largesse's, to use the term of John Adams. Socialism, whether national or international, will act in the name of "distributive justice," as well as "social justice" and "progress," and thus gain popularity. You 
don't, after all, shoot Santa Claus. As a result, these parties normally win elections, and politicians who use their slogans are effective vote-getters. The Tighten-Your-Belt parties, if they unexpectedly gain power, generally act more wisely, but they rarely have the courage to undo the policies of the Santa parties. The voting masses, who frequently favor the Santa parties, would retract their support if the Tighten-Your-Belt parties were to act radically and consistently. Profligates are usually more popular than misers. In fact, the Santa Claus parties are rarely utterly defeated, but they sometimes defeat themselves by featuring hopeless candidates or causing political turmoil or economic disaster.

A politicized Saint Nicholas is a grim taskmaster. Gifts cannot be distributed without bureaucratic regulation, registration, and regimentation of the entire country. Countless strings are attached to the gifts received from "above." The State interferes in all domains of human existence-education, health, transportation, communication, entertainment, food, commerce, industry, farming, building, employment, inheritance, social life, birth, and death.

There are two aspects to this large-scale interference: Statism and Egalitarianism, yet they are intrinsically connected since to regiment society perfectly, you must reduce people to an identical level. Thus, a "classless society" becomes the real aim, and every kind of discrimination must come to an end. But discrimination is intrinsic to a free life, because freedom of will and choice is a characteristic of person and his personality. There is, in fact, only either just or unjust discrimination. Yet, egalitarian democracy remains adamant in its totalitarian policy. The popular pastime of modern democracies of punishing the diligent and thrifty, while rewarding the lazy, improvident, and unthrifty, is cultivated via the State, fulfilling a demo-egalitarian program based on a demo-totalitarian ideology. Democratic tyranny, evolving on the sly as a slow and subtle corruption leading to total State control, is thus the third and by no means rarest road to the most modern form of slavery [39].

\section{Ramification of the Dissolution of USSR}

World changed dramatically in the last four decades, more so, since the dissolution of Soviet Union on December $25^{\text {th }} 1991$. Add to this the advancement of technology on all fronts; bigdata and lightning-fast data processing, AI, IoT, super-fast computers, and Ultra-High-Speed Broadband Internet - you get the picture. How does all this come into play for degeneration of democracy - We will get to that later in the article. Here is a, literature based, short account of why the elites in post-colonial era would not commit to effective democracy for the "common good." The global impact of Anglo-American Story is given here as Guyana looks to ABC countries for guidance and help - even though, they themselves are not the best role models as democracy in $\mathrm{ABC}$ countries has degenerated enormously. US and Britain have precolonial ties with Guyana and have vested interest in its resources as Guyana is the "Goose that is going to lay the golden eggs" - the diminutive "Kleptocrats" of Guyana are drooling to embezzle the potential oil money enabled by the money laundering "Corruption Chain" that ends in the most sought after tax heavens - US and UK [40].

\section{The Anglo-American Apologue}

How did the world's two most venerable and influential democracies - the United Kingdom and the United States - end up with Boris Johnson and Donald Trump at the helm? Both, Johnson and Trump have what the Irish physicist and psychologist Ian Hughes calls "disordered minds". There is an obvious answer to the question of how two venerable democracies installed disordered minds in power and enabled them to pursue unpopular policies. But there is also a deeper one. The common political flaw lies in the mechanics of political representation, notably both countries' (UK \& US) first-past-the-post voting systems. Electing 
representatives by a simple plurality in single-member districts has fostered the emergence of two dominant parties in both countries, rather than the multiplicity of parties elected in the proportional representation systems of Western Europe. The two-party system, which then leads to a winner-take-all politics, fails to represent voter interests as well as coalition governments, which must negotiate and formulate policies that are acceptable to two or more parties - Guyana is in the same boat. Political scientists predict that a two-party system will represent the "median voter", because each party moves to the political center in order to capture half the votes plus one. In practice, campaign financing has dominated US party calculations in recent decades, so the parties and candidates have gravitated to the right to curry-favor with rich donors. No political system can perfectly translate the public will into policy, and the public will be often confused, misinformed, or swayed by dangerous passions. The design of political institutions is an ever-evolving challenge. Yet today, owing to their antiquated winner-take-all-rules, the world's two oldest and most venerated democracies are performing poorly - dangerously so. We look to ABC countries for guidance and help - they themselves have been degenerated (Plato's words) to the extent that they are not fit to lead.

Governments have long implied that offering houseroom to laundered money harms no one, benefits Britain and ranks as "inward investment". Tony Blair and David Cameron openly welcomed Russian oligarchs, Saudi princes and Chinese property hoarders. Experts put the amount of dirty money floating around the world offshore at some $\$ 30 \mathrm{tn}$, with as much as $\$ 500$ bn removed from Russia since the fall of the Berlin wall alone.

The collapse of communism in the other post-Soviet states, along with China's turn toward capitalism, only added to the "kleptocratic fortunes" that were hustled abroad for secret safekeeping. Officials around the world have always looted their countries' coffers and accumulated bribes [41]. But the globalization of banking made the export of their ill-gotten money far more convenient than it had been - which, of course, inspired more theft. By one estimate, more than $\$ 1$ trillion now exits the world's developing countries each year in the forms of laundered money and evaded taxes. All under the watchful eyes of the mother of central banks - Bank for International Settlements. As in the Russian case, much of this plundered wealth finds its way to the United States. New York, Los Angeles, and Miami have joined London as the world's most desired destinations for laundered money. This boom has enriched the American elites (and their counterparts around the world) who have enabled itand it has degraded the nation's political and social mores in the process. While everyone else was heralding an emergent globalist world that would take on the best values of America, Palmer, had glimpsed the dire risk of the opposite: that the values of the kleptocrats would become America's own ${ }^{[42]}$. This grim vision is now nearing fruition.

\section{More than Corruption Threatens the Integrity of our Democracy}

Politicians and political parties that are now overtly funded by contributors obviously have lost sight of the intended purpose of the legitimate process of governance. Voters cannot become resigned to the fact that the political system that enunciates the constitutional right to vote and then makes the voters regret their choice, and seems like sheer mockery, is something that voters are not stuck with if voters began to use their common sense and refute the increasingly putrefied political propaganda - Fake News \& lies. Fake news is false information that is spread for a certain purpose. It has two characteristics: having a clear objective and taking on a real appearance. Fake-News has been with us since 1452 - for centuries; however, of late due to internet, its intense propensity and impact has increased tremendously [43]. Recent data on fake-news is alarming: according to the Freedom House organization, at least 30 governments paid opinion shapers to distribute online propaganda in favor of their interests in 2018, and it's predicted that in 2022, 50\% of news will be fake. Some $70 \%$ of the population of Spain is 
worried about disinformation online, a statistic that's even higher in Brazil (85\%) and next by the United States (64\%), compared to $55 \%$ of the media worldwide. And fake news on the internet is $70 \%$ more likely to be retweeted and spread 6 times faster than genuine news. People that are over 65 years old are more likely to share fake news on Facebook than younger people. And $21^{\text {st }}$ century society doesn't just inform itself through traditional media: in the United States, social media has already surpassed print media as a source of information. And it's those same social networks that are the loudspeakers for fake news, a global phenomenon that's come to stay ${ }^{[44]}$.

\section{The US's Dilemma - Lobbying}

Womack in his 2011 book, "Capitalism: Servant or Master" reiterated that there were more than 12000 lobbyists in Washington DC or about 23 per legislator. And in 2011 those lobbyists spent $\$ 4.47$ billion on lobbying; that is $\$ 6,000,000$ per legislator spent that year, $\$ 16,000$ per day per legislator for the year. Womack adds "We have a gut-level sense that we should come to the political table as equals in America, and in a very real way our outrage over corruption can be traced to the ways in which bargaining for legislative success with money leaves us far short of this ideal. It violates our basic sense of political equality-birthed in the Declaration of Independence, baptized through a Civil War, nurtured through the Progressive Era, tested and matured through the Civil Rights battles of a prior generation [45]." Guyana is also lobbying. The PPP/C on March 5 th 2019, signed a contract with Mercury Public Affairs. According to the contract, the firm will provide strategic consulting and management services specific to issues facing the party in areas of government relations and issues management for the upcoming elections. The services shall include representing the party before and arranging meetings with the Executive Branch and the Congress of the United States, the Organisation of American States and think-tanks in connection with issues relating to the anticipated general and regional elections.

\section{Corporatocracy}

Economist Jeffrey Sachs described the United States as a "Corporatocracy" in "The Price of Civilization (2011)." He suggested that "it arose from four trends: weak national parties and strong political representation of individual districts, the large US military establishment after WWII, large corporations using money to finance election campaigns, and globalization tilting the balance of power away from workers."

So, what's the difference, in a democracy, between bargaining with money and bargaining with votes? Here's one thought: the difference is that-at least in theory-everyone has an equal vote to bargain with. Not so financial bargaining power. The US Supreme Court doesn't get this. For 40 years, multiple generations of justices have shaped and mis-shaped constitutional law, and especially First Amendment doctrine, by (at times willfully) ignoring this basic insight. And now, in the case McCutcheon v. FEC, a five-to-four majority has gutted another common sense limit on big money in US politics for the same reason. The consequences for US have been dire, and are about to get worse. This is the story of how the Court's fundamentally misguided approach to money in politics has helped create a vicious cycle, ultimately leading US into a new Inequality Era in which the income gap expands endlessly and the size of a citizen's wallet determines the strength of her voice-reinforcing trends that if left unchecked will spin US towards plutocracy - some profess it already has ${ }^{[46]}$.

\section{Dirty Money and the Era of Inequality}

Schlozman et al., (2017) argue that the striking increase in economic inequality and accompanying decline in class mobility in the United States since the 1970s has been well- 
documented [47]. The US is now the single most unequal nation in the "developed world" with respect to income, and has fallen behind France and Pakistan, among others, when it comes to economic mobility [48]. A key driver of increasing inequality in the United States is the explosion in compensation to those at the top. In what Thomas Piketty calls a "hypermeritocratic society", the "peak of the income hierarchy is dominated by very high incomes from labor rather than by inherited wealth" [49]. The bottom line is that the poor in the US gaze at their wealthier compatriots across a huge and widening chasm, with scant chance of ever crossing it themselves. This reality raises a profound question. Why, in a democracywhere each citizen in theory has equal voting power, and where votes are the ultimate arbiter of who ascends to political power-would a government comprised of elected officials craft economic policies that cater to the interests of a small minority and foster rather than combat economic inequality? The answer is simple and intuitive, but some pioneering recent political science research has put the details in starker relief than ever before. The bottom line: the wealthy prefer policies that make them even richer (often by stifling mobility and security for those lower down the ladder), and government responds almost exclusively to their preferences. He who pays the piper calls the tune. It is the role of money in contemporary American politics that, more than any other single factor, drives government's differential and undemocratic responsiveness to the wealthy.

Over the past several years, scholars have proposed various pathways out of the current jurisprudential box. Some of these build out from the concept of corruption. Other theories speak to the value of political equality or the effective workings of democracy itself. And, some propose additional compelling government interests in regulating money that the Supreme Court has not considered or accepted, such as maximizing citizen participation or protecting candidates' and elected officials' time from the constant demands of fundraising so that they may focus adequately on the tasks of governance. Regardless of the exact approach, it's time for an enduring interpretation of the Constitution that empowers the People to enact protections that strive not just for clean governance, but also to make democracy work for all Americans [50]. Sachs, suggests that it could be achieved in two ways: One - to transform the Supreme Court's approach to money in politics by developing and promoting robust interpretive frameworks that go beyond corruption; promoting these ideas with legal and popular audiences; and ensuring that newly appointed justices share the public's commonsense understanding of the Constitution. Or, Two - amend the Constitution to clarify that the People have the power to rein in the influence of big money. Either way will do-but it's time to get moving - lest we forget, what happens in US has global implications [51]. Though, the Kleptocracy Asset Recovery Initiative (2010) and the Money Laundering and Asset Recovery Section (MLARS) - comprising of seven units and associated teams, are making some progress in asset forfeiture and anti-money laundering enforcement - we still have a long way to go.

\section{The Kleptocracy Curse}

Bullough, in his 2019 book "Moneyland" accounts that The United States needs to start paying attention to what has happened to the world economy. Gigantic sums of money are now traveling the world incognito. This has turned globalization into the golden age of money laundering. Nestling in Western economies are offshore financial structures (and their professional enablers) which allow funds to instantaneously and anonymously jump between countries, empowering authoritarians and corrupting Western institutions. This now presents a growing national security threat. Across the world, money laundering on an epidemic scale is undermining western nations' foreign policy: crippling development, threatening democracy, damaging Western soft power and fueling state collapse. Across the West, this staggering flow of illicit funds has turned authoritarian kleptocrats into powerful players increasingly able to wield power inside Western institutions and game them to their own ends. There is only one 
way to block the illicit flows that empower kleptocrats and undermine democracy: Ending "anonymous shell companies" must become a national security priority for the US, UK and the world [52].

Panglossian confidence has underestimated $21^{\text {st }}$ century authoritarianism. Rather than retreat, democratize, and reform towards the rule of law, the autocratic ruling classes of Russia, China, Central Asia, the Arabian Gulf, and beyond have globalized with great success. The openness of the new century, the US and the EU are now finding, is in fact rather well suited to the kleptocratic dictator-with a coterie of American lawyers, French bankers, German accountants, and British public relations teams in tow. This is because globalization has created the golden age of money laundering. Today, according to the International Monetary Fund, up to 5 percent of the world's GDP ( $\$ 76 / \mathrm{Tn}-2016$ \& $\$ 88 / \mathrm{Tn}-2019$ ) is laundered money-and only 1 percent of it ever gets spotted. It has never been simpler or safer to be a kleptocrat. Globalization's deep, structural motors are in fact enabling authoritarians. Not only can capital now mask itself and disappear without any trace, but gigantic sums of money are now traveling the world in a concealed manner. Little by little, this has made the Western financial system hospitable to kleptocrats. Behind all the outrage, the Manafort and Cohen convictions show that Trump's government is building an American Kleptocracy. The Washington Post has described how kleptocracy, or "rule by thieves," arises when a country's elite begin to systematically steal from public funds on a vast scale. Beyond the human cost of kleptocracy is the danger that progressively draining the country of money creates the sort of inequality that leads to social and political unrest. Guyana has its own class of kleptocrats who have been draining Guyana for the last five decades - their frequent trips to Miami, New York and London are, apparently, not for tourism.

Why is anonymity so important? This is the successful criminal's dilemma. Once you are successfully stealing, your problem becomes not simply the ability to steal more, but the ability to launder these ill-gotten gains effectively. The successful criminal is accumulating dirty black cash that he/she cannot easily use or secure, and needs to convert it into clean white cash: this is why money laundering is so important. The easier it is to launder money, the richer, more powerful, and more influential criminals become, and the quicker it becomes for the proceeds of crime to turn into new sources of power and activity. This is why nothing is more beautiful for a corrupt dictator (or a political elite) than the ability to anonymously and untraceably move enormous sums electronically around the world. This empowers him, both at home and abroad [53].

The Kazakhs Affray - This becomes crystal clear when one observes how the autocratic clique that rules Kazakhstan experiences the West. This country has been ruled since 1988 (before its 1991 independence from the Soviet Union) by Nursultan Nazarbayev. This Central Asian dictator frequently jails and exiles his opponents and routinely rigs elections and persecutes Kazakhstan's opposition parties. While Western embassies in his new purpose-built capital of Astana speak about anti-corruption and democratic reform, Nazarbayev and his clique interact with the West through its enablers. The ruling elite has both done business with and entertained members of Britain's royal family. Nazarbayev himself has employed both the former British prime minister, Tony Blair, and the former Austrian president, Alfred Gusenbauer, to promote his influence in the West - lobbying for him. Not only does Nazarbayev own a palatial mansion on London's Bishops Avenue, known as "Billionaires' Row," but his wealth and that of his clique has been funneled out of the country by exploiting offshore networks. In the $21^{\text {st }}$ century Nazarbayev is not the exception, but the norm; he is paradigmatic of the new authoritarians for whom there is no containment. 
Nazarbayev, is the new normal; contemporary authoritarians are mostly kleptocrats. This means corruption is not a feature of their regimes, but rather the invariable nature of their rule. An unforeseen consequence of globalization is that it has never been easier to be a kleptocrat. Corruption is used to create power bases, cement regimes, forge political alliances, and eliminate foes. Amassing extraordinary levels of wealth, as both a tool and a pleasure of power, was considerably riskier in a world of segregated, more independent national financial systems. Corrupt bureaucrats today can steal immense fortunes and then launder them immediately into offshore funds, from which they can then easily sequester these assets in the West. Their behavior is guided by a simple logic: amassing extreme wealth is fraught with risk in a political system without the rule of power, but this risk disappears if you can steal in a system without the rule of law and sequester assets safely in the West. Rather than a bloc challenging kleptocratic behavior, the West today is experienced by such elites as a welcoming financial system and professional class that exists to abet and enable them. Once Nazarbayev has hired a former prime minister and a former president as consultants, why should he take the British and the Austrian embassies seriously when they lecture his government on anticorruption? Oliver Bullough's book, Moneyland (2019), is a good read on the topic: The Inside Story of the Crooks and Kleptocrats Who Rule the World opens with the simultaneously delicious and disturbing accounts of the excesses and corruption of Paul Manafort and Rick Gates as well as Viktor Yanukovych, the disgraced former president of Ukraine [54].

\section{OTHER IMPEDIMENTS TO THE SUCCESS OF DEMOCRACY}

\section{Illiteracy}

The Consequences of Illiteracy - Recent research in the fields of psychology, nutrition and neuroscience suggest that the first five years of life are critical to the development of intelligence, personality and social behaviour. It is during this period that millions of cells are born, grow and become interconnected. When this process of growth, development and interconnection does not take place adequately, child development is negatively affected. "The World Declaration on Education for All" states that education begins at birth and continues throughout life. Consequently, the social effects of illiteracy are present throughout the entire life cycle. During early childhood, the effects of illiteracy can be seen within the family unit and the primary socialization process. Later, during adulthood, illiteracy affects an individual's social position, income and cultural capital [55].

Illiteracy is a social justice issue and impediment to the success of democracy - Think about it: When someone cannot read, they are excluded from many of the things that allow us to be fully functional citizens with choices. Illiterate persons face greater obstacles in terms of social insertion, not only on a personal level (social inclusion difficulties, precarious work, high rates of disease, etc.), but also within the family (child nutrition, hygiene, health and schooling, among others) and at a societal level (lower productivity, high health care costs). The social consequences of adult illiteracy can be divided into the following categories: health, education, social integration and cohesion. Those who are illiterate can lack access to information, are excluded from making choices about their rights or government through voting, and have fewer opportunities for employment. Illiteracy keeps people trapped in a cycle of poverty and subjugation, limiting life choices and making it difficult to achieve social mobility. Literacy truly is power - power over one's own life.

Giroux, emphatically establishes that "We need to educate people so that they can value their vote and become healthy participants in democratic process of governance." He goes on to emphasize that - Stripped of its ethical and political importance, the public has been largely reduced to a space where private interests are displayed and the social order increasingly mimics a giant Dr. Phil show where notions of the public register as simply a conglomeration of 
private woes, tasks, conversations and problems. Most importantly, as the very idea of the social justice collapses into an utterly privatized discourse, everyday politics is decoupled from its democratic moorings and it becomes more difficult for people to develop a vocabulary for understanding how private problems and public issues constitute the very lifeblood of a vibrant politics and democracy itself. This is worth repeating. Emptied of any substantial content, democracy appears imperiled as individuals are unable to translate their privately suffered misery into genuine public debate, social concerns and collective action. This is a form of illiteracy that is no longer marginal to society but is increasingly becoming one of its defining and more frightening features.

The raging narcissism that seems to shape every ad, film, television program and appeal now mediated through the power of the corporate state and consumer society is not merely a clinical and individual problem. It is the basis for a new kind of mass illiteracy that is endlessly reproduced through the venues of a number of anti-democratic institutions and forces that eschew critical debate, self-reflection, critical analysis and certainly modes of dissent that call the totality of a society into question. As society becomes incapable of questioning itself, the new illiteracy parades as just its opposite. We are told that education is about learning how to take tests rather than learning how to think critically. We are told that anything that does not make us feel good is not worth bothering with. We are told that character is the only measure of how to judge people who are the victims of larger social forces that are mostly out of their control. When countless people are unemployed, tossed out of their homes, homeless or living in poverty, the language of character, pop psychology, consumerism and celebrity culture are more than a diversion: they are fundamental to the misdirected anger, mob rule and illiteracy that frames the screaming, racism, lack of civility and often sheer and legitimate desperation [56]. The difficulty understanding societal issues lowers the level of community involvement and civic participation. Without the basic tools necessary for achieving their goals, individuals without an adequate level of literacy cannot be involved fully and on a completely equal basis in social and political discourse. However, there isn't one magic solution to a nation's literacy problem - mostly because its causes aren't singular. There are "Two Generation" programs that afford both children and their parents with education, job training, and community assistance. Nearly two-thirds of the world's illiterate adults are women according to a UN 2015 Report [57].

\section{Age of Injustice}

Nothing rankles more in the human heart than the feeling of injustice [58]. In Western philosophy and jurisprudence, injustice is very commonly - but not always - defined as either the absence or the opposite of justice. According to Michael Mansfield QC, the 'Justice Gap' refers to the increasing section of the public too poor to afford a lawyer and not poor enough to qualify for legal aid. At the heart of any notion of a decent society is not only that we have rights and protections under the law but that we can enforce those rights and rely upon those protections if needed. The basic measure of the "Justice Gap," as a recent report by the Legal Services Corporation calls it, the 2017 report concluded that this "gap" in fact "has stretched into a gulf." The World Justice Project Rule of Law Index® measures how the rule of law is experienced and perceived by the general public in 126 countries and jurisdictions worldwide. The rule of law is a framework of laws and institutions that embodies four universal principles: 1- Accountability; 2 - Just Laws; 3 - Open Government; and 4 - Accessible \& Impartial Dispute Resolution. The government as well as private actors are accountable under the law. In Rule of Law Index 2019 Guyana stands at \#75 out of the 126 countries. Barbados-29, and T\&T-55. In LAC out of the 30 regional nations; Uruguay is \#1, Barbados at \#4, Trinidad \& Tobago at \#14, and Guyana at \#19 - by any standard it is a dismal record [59]. 


\section{Voter Apathy is Counterproductive to Effective Democratic Rule}

Voter apathy refers to a lack of interest in participating in elections by certain groups of voters. One side-effect of voter apathy can be low voter turnout on election day if voting is noncompulsory. In countries or areas with compulsory elections, voter apathy may manifest itself in the form of a high proportion of spoilt ballots or donkey votes. Almost 92 million eligible Americans did not vote in the 2016 presidential elections; in 2018 local general elections in Guyana $64 \%$ of the eligible voters did not vote. This may be because of unnecessary barriers in the voter registration and voting process that prevent would-be voters from casting ballots or because potential voters feel alienated from government or voters were persuaded by the fakenews or hacking.

Main possible causes of Voter Apathy include: Alienation - this refers to the sense that voters feel like the political system does not work for them and any attempt to influence it will be a fruitless exercise; Voter fatigue - this means that elections are simply deemed to be occurring too often; Barriers to Voting Registration process etc.; Lack of Trust in Politicians and Political System; Voter suppression, including improper voter purges; Digital social media platforms harming democracy by allowing the spread of fake news.

Voting is a foundational right and responsibility of citizens in all democratic nations. Political scientists have shown conclusively that voting participation, at least in the US, is strongly correlated with income. Richer people vote more. This form of social inequality is troubling on a number of levels. In practical terms, this pattern appears to have distortionary downstream effects on representative government - reinforcing patterns that bias public policy towards the wealthy. One of the most consistent findings in studies of electoral behaviour is that individuals with higher education have a greater propensity to vote.

\section{Democracy Hijacked - The Great British Brexit Robbery}

The connectivity that is the heart of globalisation can be exploited by states with hostile intent to further their aims. The risks at stake are profound and represent a fundamental threat to nations' sovereignty. This is the account of a British company, SCL, with 25 years experience in military Psyops "psychological operations" and "election management". The company, SCL Elections, went on to be bought by Robert Mercer, a secretive hedge fund billionaire, renamed Cambridge Analytica, and achieved a certain notoriety as the data analytics firm that played a role in both, Brexit and Trump campaigns. Psyops. Psychological operations - the same methods the military use to effect mass sentiment change - by winning hearts and minds. Cambridge Analytica - a Data analytics company formed in 2014 (Robert Mercer owns 90\% \& SCL owns 10\%); carried out major digital targeting campaigns for Donald Trump campaign, Ted Cruz's nomination campaign. White House strategy chief Steve Bannon was on the payroll of Cambridge Analytica. To anyone concerned about surveillance, Palantir is practically now a trigger word. The data-mining firm has contracts with governments all over the world including GCHQ (Government Communications Headquarters) and the NSA (National Security Agency). It's owned by Peter Thiel, the billionaire co-founder of PayPal and major investor in Facebook, what's clear is that the power and dominance of the Silicon Valley - Google and Facebook and a small handful of others - are at the centre of the global tectonic shift we are currently witnessing. It also reveals a critical and gaping hole in the political debate in Britain. Because what is happening in America and what is happening in Britain are entwined [60].

There are three strands to this story. How the foundations of an authoritarian surveillance state are being laid in the US. How British democracy was subverted through a covert, farreaching plan of coordination enabled by a US billionaire. And how we are in the midst of a massive land grab for power by billionaires via our data. Data which is being silently amassed, 
harvested and stored. Whoever owns this data owns the future. The key to understanding how a motivated and determined billionaire could bypass US \& UK electoral laws rests on AggregateIQ, an obscure web analytics company based in an office above a shop in Victoria, British Columbia, Canada. AggregateIQ had just been a short-term "contractor" to Cambridge Analytica. There was nothing to disprove this [61]. A working group set up by the London School of Economics warns that new ultrafast digital technology enabling Big-Data manipulation has disrupted British politics to such an extent that current laws are unable to ensure a free and fair election or control the influence of money in politics. SCL/Cambridge Analytica was not some start-up created by a couple of guys with a Mac PowerBook. It's effectively part of the British defence establishment. And, now, too, the American defence establishment. Iota Global, a partner of the SCL group.

Cambridge Analytica Exploited Facebook - This is not just a story about social psychology and data analytics. It has to be understood in terms of a military contractor using military strategies on a civilian population. An extraordinary scandal that this should be anywhere near a democracy. It should be clear to voters where information is coming from, and if it's not transparent or open where it's coming from, it raises the question of whether we are actually living in a democracy or not. Cambridge Analytica introduced mass data-harvesting to its psychological warfare techniques. It brought psychology, propaganda and technology together in this powerful new way; and it was Facebook that made it possible. It was from Facebook that Cambridge Analytica obtained its vast dataset in the first place. Facebook was the source of the psychological insights that enabled Cambridge Analytica to target individuals. It was also the mechanism that enabled them to be delivered on a large scale. The company also (perfectly legally) bought consumer datasets - on everything from magazine subscriptions to airline travel - and uniquely it appended these with the psych data to voter files. It matched all this information to people's addresses, their phone numbers and often their email addresses. The goal was to capture every single aspect of every voter's information environment; and the personality data enabled Cambridge Analytica to craft individual messages. Finding "persuadable" voters is key for any campaign and with its treasure trove of data, Cambridge Analytica could target people high in neuroticism, for example, with images of immigrants "swamping" the country. The key is finding emotional triggers for each individual voter. As Miller describes; it's not a political consultancy, one has to understand this is not a normal company in any way and, apparently, Mercer even cares if it ever makes any money. It's the product of a billionaire spending huge amounts of money to build his own experimental science lab, to test what works, to find tiny slivers of influence that can tip an election. Robert Mercer did not invest in this firm until it ran a bunch of pilots - controlled trials. This is one of the smartest computer scientists in the world. He is not going to splash $\$ 15 \mathrm{~m}$ on something worthless. Democracies are in the midst of an information war and billionaires are buying up these companies, which are then employed to go to work in the heart of governments. That's a very worrying situation.

Trinidad \& Tobago Project 2013 - A project that Cambridge Analytica carried out in Trinidad in 2013 brings all the elements in this anecdote together [62]. SCL was retained by several government ministers in Trinidad and Tobago. The brief involved developing a micro-targeting program for the governing party of the time. And AggregateIQ - the same company involved in delivering Brexit for Vote Leave - was brought in to build the targeting platform. As per Miller: "The standard SCL/CA method is that you get a government contract from the ruling party. And this pays for the political work. So, it's often some worthless health project that's just a cover for getting the minister re-elected. But in this case, our government contacts were with Trinidad's national security council." The security work was to be the prize for the political 
work. Documents seen by the Observer show that this was a proposal to capture citizens' browsing history en-masse, recording phone conversations and applying natural language processing to the recorded voice data to construct a national police database, complete with scores for each citizen on their propensity to commit crime. The plan put to the minister was Minority Report. It was pre-crime. And the fact that Cambridge Analytica is now working inside the Pentagon is absolutely terrifying. These documented events throw light on a significant and under-reported aspect of the Trump administration. The company that helped Trump achieve power in the first place has now been awarded contracts in the Pentagon and the US state department. Its former vice-president, Steve Bannon sat in the White House. It is also reported to be in discussions for "military and homeland security work". 90 million voters did not vote in 2016 US election - perhaps a number of them, believed to be, manipulated into 'not to vote', by the AggregateIQ cajolery. In the US, the government is bound by strict laws about what data it can collect on individuals. But, for private companies anything goes. It is not unreasonable to see in this the possible beginnings of an authoritarian surveillance state - "Deep State" comes to mind $[63,64]$.

The details of the Trinidad project finally unlocked the mystery that was AggregateIQ. Trinidad was SCL's first project using big data for micro-targeting before the firm was acquired by Mercer. It was the model that Mercer was buying into. And it brought together all the players: the Cambridge psychologist Aleksandr Kogan, AggregateIQ, Chris Wylie, and two other individuals who would play a role in this story: Mark Gettleson, a focus group expert who had previously worked for the Lib Dems. And Thomas Borwick, the son of Victoria Borwick, the Conservative MP for Kensington. In his blog, Dominic Cummings writes that "Brexit came down to 'about 600,000 people - just over $1 \%$ of registered voters'. It's not a stretch to believe that a member of the global 1\% found a way to influence this crucial $1 \%$ of British voters. And that we, the British people, were played. This is Britain in 2017. A Britain that increasingly looks like a 'managed' democracy. Paid for by a US billionaire. Using military-style technology. Delivered by Facebook. And enabled by us. If we let this referendum result stand, we are giving it our implicit consent. This isn't about Remain or Leave. It goes far beyond party politics. It's about the first step into a brave, new, increasingly undemocratic world."

More than 100 election campaigns in over 30 countries spanning five continents. That's the astounding, self-proclaimed track record of SCL Elections, the parent company of Cambridge Analytica (CA), a once little-known British political consulting firm that now finds itself in the eye of a storm roiling the US, UK, and Facebook. Earlier this month, it was revealed that CA, which was hired by Donald Trump's campaign to build targeted ads during the 2016 US election, harvested data from 50 million Facebook users without their consent. CA's role in the closely fought Brexit referendum in the UK is also under scrutiny. There are no other companies that can compete with SCL in gathering the necessary data and analyzing it in a way that permits the design of effective, data-driven influence campaigns. SCL's behavioral influence and microtargeting techniques are increasingly commonplace in digital electioneering. In the years after its reboot, SCL's election work-increasingly under the guidance of Nix-grew at a better rate than its defense portfolio. Some of the firm's campaigns in the Commonwealth Caribbean during that time have earned the scrutiny of British lawmakers, who wrote last year that the campaigns "were not financed in a transparent way, overstepping legal and ethical boundaries." In those former British territories, SCL chose its clients on behalf of interests connected to the global passport investment industry, using those contracts to test and refine dubious campaign tactics, as the Spectator and Fast Company reported; Caribbean countries included - Guyana, Trinidad and Tobago, Grenada, St Vincent \& Grenadines, Saint Lucia, St Kitts \& Nevis, and Antigua \& Barbuda [65]. 
However, solutions to the above problems are forthcoming. Delinquent entities; who harvested data from millions of Facebook users, manipulated through deceptive practices, and hacked our democracy, are now redressing netizens' privacy concerns. Brittany Kaiser, an American and former business development director for Cambridge Analytica, believes there is an entire new industry around digital identity, data ownership, data management and data monetisation. Now, a slew of tech entrepreneurs is bidding to turn growing consciousness about the problem into a money-making industry and many showcased their skills at WebSummit in Lisbon held on Nov. 2-5, 2019 - assuring to provide personalised encryption at the level of the device, so that any key stroke on your device is unreadable by a third party. The Lisbon Web-Summit speakers emphasized that the way ahead is "privacy by default." US currencies guru David Chaum, the "godfather of crypto," meanwhile said he believed the digital world has reached a key juncture. This is like a kind of a historic moment, he added, "if you look at smartphones, the killer app is clearly messaging integrated with payments." Chaum is behind Elixxir, which seeks to offer digital privacy by deploying a mobile messaging app partnered with a virtual payment vehicle along the lines of Chinese behemoth Tencent's WeChat platform, securing communications through blockchain protection [66].

4.6 Will Technology Kill Democracy - Or Reinvent It

Fuller (2019), in her book, In Defence of Democracy, argues that once upon a time, many thought the internet would spawn a digital democratic utopia: harmonious, boundaryspanning decision-making, reflecting liberty and equality in a global community of "netizens." Today, sadly, we witness identity theft, cyber-bullying, manipulative analytics, fake news, and authoritarian surveillance - hacking elections and polarizing open societies. Social media companies are hiring thousands of editors to fight hate speech and robotic information corruption, while US state election commissions are scrambling to reinstate paper ballots. Will today's democracy survive the onslaught of technology-delivered malice? Yes, maybe: but only if we stop blaming bits and bytes, forget about "global democracy," and instead tackle the structural deficits of our current representative systems of national self-governance. This lively polemic assert that the problem for western civic societies is not so much defending against hostile and abusive use of technology. Instead, it's failing to use technology to rediscover what democracy should be for the modern nation state: citizens participating personally in public debate and having meaningful say in policy decisions that affect them - without the distorting and corruptible role of legislative proxies or elitist agency officials. If we're going to defend and keep alive - democracy today, she insists, we need a revolution: go back to what the ancient Athenians invented in the $5^{\text {th }}$ century BCE, where every citizen regularly participated in discussion and voting for the laws that would steer their livelihoods and survival. Dr. Fuller believes new technology and communication tools can now provide the means to scale up for millions of people what ancient Athenians did with perhaps (at most) 50,000 citizens. Fuller's, central premise is that any modern representative democracy - e.g. U.S. constitutional government, or Britain's "monarch-lite" parliamentary model - will inevitably slide towards a gridlocked, gerrymandered, influence-peddled partisan morass. "The small number of seats in legislatures serving a major population means elections aren't really representative - allowing money to grow in influence, which in turn sets up factional fighting and winner-take-all strategies. Meanwhile, what these representatives discuss is increasingly out of touch with most common people's priorities - leading to rising frustration, disengagement, and declining voter turnout. Which then invites more winner-take-all by powerful interests and increasing partisan focus on policy that entrenches elites. To break the cycle, we have to authentically give power back to the people [67]." 


\section{Analog vs. Digital Generations}

We've all heard about "The Greatest Generation," "the Baby Boomers, " and Generations X, Y, and $Z$. These are all labels used to describe and contrast the characteristics of the various age groups of people. But there is an easier way of differentiating people, namely Analog vs Digital; not through age but by how well you have adapted to technology - the description is simple, yet profound, in terms of differentiating people. Rand McNally vs GPS and Land Lines vs Wireless World has come a long way. However, Guyana for the last four decades is in the grasp of analogue generation - stuck in this rut, it has deprived itself of advancement. Globally, the digital revolution is in full force but many public and private sector leaders are stymied; private companies and governmental bodies fall well behind other digital pioneers as they are yet to maximize the full potential of digital technology and big-data. Consumers can deploy new digital technology to improve health care, gain access to education, learn from the news media, and check public sector performance. New storage platforms such as high-speed broadband, mobile communications, and cloud computing enable and improve both social and economic development. However, to gain these benefits, policymakers must recognize the legitimacy of public fears about technology and the privacy and security dangers posed by the Internet. Their goal must be to further innovation and investment while also protecting basic social and individual values. Scholars argue that digital technology innovation is consistent in many ways with personal and social values; people can deploy digital technology to improve participation and collaboration, and political leaders can work with the private sector to stimulate a flowering of innovation in a variety of policy areas [68,69]. It is about time that the analogue generation of political elites in both the main political parties let go and allow the digital generation to play a decisive role in Guyana's politics and development.

\section{Global Democracy - is it Undermining National Democracy?}

It has become accepted, among most experts on democracy, and among policymakers, that democracy worldwide is in increasing peril. This year's Freedom in the World Annual Report (2019) on the state of democracy, produced by Freedom House [70] noted that democracy had declined globally for thirteen years in a row. It further found that authoritarian states were "shedding the thin façade of democratic practice that they established in previous decades," while "countries that democratized after the end of the Cold War have regressed in the face of rampant corruption, antiliberal populist movements, and breakdowns in the rule of law" and that even consolidated democracies, in Europe and North America, faced severe pressure, backsliding, and corrosion of democratic institutions and norms. The 13 years of decline have touched all parts of the world and affected Free, Partly Free, and Not Free countries alike.

This decline, however, is also linked to Global Democracy. A field of academic study and political activism concerned with making the global political system more democratic - it is therefore concerned with how transnational decision-making can be justified and who should be entitled to participate in the formation of global rules, laws, and regulations. Most scholars agree that democracy refers to a political practice in which individuals govern themselves through some form of equitable decision-making process. This leaves open two fundamental issues: who constitutes 'the people' and how 'rule-making' should occur. National democracy is typically institutionalized as a representative system that involves competitive elections and a publicly determined rule of law. Although there are many different national voting systems (majority rule, proportional representation, etc.), the basic idea is that each enfranchised citizen of the state has one vote at the ballot box and can thus freely choose their preferred representative, leader, or party. Over time, then, 'the people' in democracy has been assumed to correspond neatly with the citizenry of each particular nation-state. 
In recent years, however, the supposed alliance between democracy and the nation-state has come unstuck. This is due predominantly to globalization: the increased extent, velocity, and scope of cross-border interactions, transactions, and relations. Globalization intensifies social, political, financial, and economic relations through technological changes and the flow of people, resources and ideas across state lines. The expansion of global connections has gone hand-in-glove with increased efforts to govern global affairs. Countless formal measures, informal norms and overarching discourses for regulating global affairs are now formulated and implemented through complex transnational networks that combine sub-state agencies, nation-states, regional bodies, global institutions, and non-state actors. Although the state is often an active participant in globalization, many scholars have argued that increased transnational activity undermines national democracy - Globalization pierces the sovereignty of nation-states by subjecting domestic affairs to transnational decision-making. Moreover, citizens of each state are often said to be problematically excluded from global activities in ways that lead to a democratic deficit [71].

The Global Democratic Deficit - The array of transnational institutions that govern social, political, and economic processes is bewildering. As the number of these transnational institutions has increased with globalization, so too has their capacity to exercise authority [72]. This occurs through international law-making, regulatory standard-setting, and the promotion of new norms. As decisions are taken outside the state, national leaders are unable to control the forces which impact domestic institutions and citizens. Correspondingly, and resultantly, individuals within each state have no direct say in how global rules are forged. This undermines the notion that individuals can collectively govern their joint affairs. This gap, between individual rule-takers and transnational rule-makers, is referred to as the global democratic deficit.

The global democratic deficit is compounded by at least three additional factors. First is an issue of procedure: international bodies often operate with unaccountable and nontransparent processes. This makes it difficult to identify the steps in a causal chain which link transnational rule-makers with rule-takers. The second factor is scope: current arrangements of transnational institutions seem incapable of tackling the most pressing issues of a globalizing world - climate change, spread of infectious diseases, volatile financial markets, enormous poverty rates, unjust supply chains, just to name a few. Third is an issue of constituency: globalization is actually reshaping who constitutes 'the people' due democratic standing in decision-making processes.

This final point bears emphasis because it has reignited debates in democratic theory over the so-called 'boundary problem': who is entitled to take part in democratic decision-making processes [73]? This question is often thought to be paradoxical because democratic theory offers no internal solution for delineating 'the people': unless we already know who is eligible to participate in democratic procedures, we do not know who to include in the initial decisionmaking process. As globalization erodes the idea that the citizenry represents a natural embodiment of 'the people', we need to search for alternate ways to justify democratic inclusion.

Global Undemocratic Extractive Institutions - Acemoglu and Robinson explore the nature of economic growth and failure in "Why Nations Fail: The Origins of Power, Prosperity, and Poverty", looking at the world through the combined perspectives of an economist and a political scientist. They argue that whether or not a nation achieves sustained economic 
growth is due to the existing political and economic institutions; divided into two fundamentally separate categories - inclusive and extractive.

Inclusive economic institutions are those that allow and encourage participation by the great mass of people in economic activities that make the best use of their talents and skills - they make their own decisions about their work lives. This definition, also, necessitates that broad swathes of a country's population must be included in economic activity. Likewise, to be inclusive, economic institutions must feature secure private property, an unbiased system of law, and a provision of public services that provides a level playing field in which people can exchange and contract. The presence of private property creates incentives for citizens to achieve success in the long term. This, combined with a system that includes the bulk of the population, allows for a system that achieves near-maximum utility of its human and physical resources. On the other hand, extractive institutions remove the majority of the population from participation in political or economic affairs and favor the elite who are in charge, allowing them to pull materials and opportunities from those that live under them. Throughout history, extractive institutions have typically led to stagnant economic growth. After the second world war, most of the International institutions such as World Bank, IMF, WTO, Bank for International Settlements, etc. were set up as inclusive institutions; however, in the last four decades, they have turned into extractive institutions working for the 1\% elite - Bankers [74]. World Bank and IMF, both undemocratic global institutions, make rules and apply them onto nations who have no say in the process. They are on the receiving end. World Bank and IMF have played an immense role in impoverishing the Latin America Caribbean and African nations and turning them into loan addicts [75]. Lack of control over nation's fiscal policy subverts their ability to develop and undermines national democracy.

Under Trump, America is in the business of actively creating or deepening threats to the world - worthy of being called a "rogue state" [76]: weaponization the US dollar for geopolitical purposes; capsizing the climate; pardoning U.S. soldiers and military contractors convicted of war crimes; Regime change interventions in Afghanistan, Iraq, Sudan, Libya, Yemen, Venezuela and others; American illegal presence in Syria - giving Golan Heights to Israel and now stealing its OIL; supplying arms to Saudi Arabia, so that the kingdom can bombard Yemen. For a while, it looked as if Trump might attack North Korea; it's still possible that he will start a war with Iran. In recently leaked memos, Kim Darroch, the former British ambassador to the U.S., worried that Trump would wreck world trade. Along the way, his administration has trashed so many diplomatic rules and norms that the entire edifice of postwar multilateralism is at risk. Deposition of Morales, in a US "deep state" sponsored coup, on Nov $10^{\text {th }} 2019$ is no coincidence [77, 78]; Morales is indigenous president, who freed Bolivia from IMF, and wants Bolivian resources for the Bolivians. On Nov $4^{\text {th }} 2019$, Morales, scraped the "Lithium" joint venture between Bolivian state company YLB and the German company ACISA- and was going to sign a deal with China's Tianqi Lithium Group, which operates in Argentina, to work with YLB Morales was ousted a week after [79]. Morales was toppled not due to his failures, but due to his success. Bolivia is set to remain in turmoil, unless external forces turn to constructive engagement and away from self-interested meddling. Guyanese zealots, eager to renegotiate Exxon's and other oil contract, should take note.

\section{CONCLUSION}

Armed with the doctrine of discovery and acting on the bestowed privileges of papal bulls of 1452, 1455, 1493; all Christian nations plundered Americas and the Caribbean for next five centuries - all in the name of, perverted dictum, God, Glory \& Gold. The genocides, institutionalized-injustice and systematic atrocities perpetuated by the European monarchies ravaged Americas, Caribbean, and African nations; inflicting irreversible devastation that 
persists to this day. Guyana's underdevelopment is rooted in the past five centuries of colonial policies of the Spain, France, Dutch, and Britain. The British set-up merest infrastructure and bare extractive institutions that facilitated the maraud of Guyana's resources - while keeping its population in abject poverty. It would be duplicitous to consider that the British along other European looters were, even remotely, interested in the development of the peoples of Guyana. The Doctrine of Discovery is still being used by countries throughout the Americas to deny the rights of indigenous peoples, and to eternalize colonization throughout the Americas. The transfer of power in British Guiana was not simply the accession to office in an independent country by the nationalist elite; it also transferred control of the country's political system and economic and foreign policy to the United States. However, after the independence the extraction and looting of resources of Guyana continued; colonial powers had planted their cronies as the new leaders - these kleptocrats have been loyal to their masters ever-since.

UK and US undermined Guyana's democratisation and development, focussing instead on maintaining physical order and control in sustaining economic extraction through "Overdeveloped State" - under Burnham, the overdeveloped state became a class in itself. Guyana, after independence, kept its pre-colonial state machinery, institutions and oppressive justice system operating; primarily to help maintain the new elites', turned kleptocrats, powerbase. Solving post-colonial problems via pre-colonial institutions is preposterous. Guyana's Winner-Takes-All politics, hinged on racially-divided two party system, have not delivered inclusive development to Guyana since independence in 1966. US and Britain have precolonial ties with Guyana, and having vested interest in plundering its resources; they continue meddling in Guyana's political and economic affairs. The diminutive "Kleptocrats" of Guyana, who have been draining Guyana for the last five decades, are now drooling to embezzle the potential oil money facilitated by globalization-enabled golden age of money-laundering-chain ending in the most sought-after tax heavens - US \& UK.

\section{THE WAY FORWARD - RECOMMENDATIONS}

Guyana is ravenous for legitimate, antidotal, constitutional reforms that can guarantee the desired outcome for satisfactory governance in all the five elements of democracy. A decentralised, pragmatic, governing model where distribution of political power among Legislature, Executive, and Judiciary is distinctly separated while ensuring that the governance is: participatory; transparent; accountable; responsive; equitable; and inclusive in its approach. In terse, Governance would adhere to three areas: Uphold the Rule of Law; Inclusive Democracy and Political Participation; and Effective Governance for the Common Good prosperity for all. Guyanese have to strive for inter-ethnic reconciliation and political consociation through multiparty system for 2020 elections. First and foremost, Guyana needs to restore the indigenous peoples "Human Dignity, Rights and Identity"; rid Guyana of the antiquated, repressive colonial institutions; and reform the archaic education system. It is imperative that we establish an intimate connection between knowledge considered basic to any school curriculum and knowledge that is the fruit of the lived experience of these students as individuals [80].

Lack of proper infrastructure profoundly impedes the development of resource rich Guyana's hinterlands regions and has rendered their population indigent; proposed $21^{\text {st }}$ century " $\mathrm{Hub}$ and Spoke" model for infrastructure development will support Micro and SMEs and foster Wellbeing Economy [81]. The Fourth World; the world of small nations, small communities and small enterprises is the only world that can be democratic and reflect genuine human needs or desires. To actualize "inclusive sustainable development" and to ensure "food \& energy security", the way forward is to promote Microenterprise in Short Supply Chain using Appropriate 
Technology working towards Right Livelihoods incorporating Human Scale Development by giving due rights to the Invisibles and, in planning, populations be measured in terms of Ecosons [82].

Despite the discovery of Oil, Guyana needs to, emphatically, follow the green development strategy and strenuously add to the energy mix Renewable Energy Sources including; solar, wind, hydroelectric, and biomass. Micro ultrasonic biodiesel production [83], using Bio-Wrap model, can play an integral role in replacing petro-diesel, in almost all, Guyana's power \& transport sectors' requirements [84]. Green Social MSME are vital in making developmentoriented growth happen, and especially in reaching the most vulnerable population at the grassroot. In addition to economic performance; and for this to materialize it is imperatively vital to incorporate sustainable social and environmental benefits within their business model - economic value is crucial for the sustainability of social entrepreneurial ventures and the creation of social value [85]. Guyana needs a legislated Local Content Policy (LCP), with embedded CSR strategy, to ensure that extractive industries benefit Guyanese citizens. Local Content effective design, development, implementation and monitoring of LCP can lead to the amelioration of the structural effects of Oil Gas \& Mineral sector through: Increased value added; Increased employment generation; technology transfers, innovation, and social investments in capacity building and development of skills; Poverty Reduction; Enhanced entrepreneurial development; Improvements in local investment in the sector; and Increased contribution to GDP. Anti-corruption mechanisms could include: the adoption of rules regulating conflicts of interest, revolving door, and gifts and entertainment; mandatory requirements for public officials and senior executives of state-owned enterprises to regularly declare their assets with mandatory prosecution and sentencing for violators; the adoption of access to information laws and rules opening the decision-making process, particularly ensuring civil society participation and oversight in the negotiation of oil agreements and other public agreements, and to modify the present Legislation on Unexplained Wealth based on UK model of "Unexplained Wealth Orders" under the UK Criminal Finance Bill and ENFORCE the legislation without prejudice [86].

To restore the degenerated democracy in Guyana, GECOM has to ensure that democracy is neither hacked nor hijacked. Voter-Apathy is counterproductive to effective democratic rule: resolving voter-apathy concerns would secure participative democracy through fair elections in 2020, and set in motion the process of restoring hope for the nation. Voters cannot become resigned to the fact that the political system that enunciates the constitutional right to vote and then makes the voters regret their choice; and seems like sheer mockery, is something that voters are not stuck with if voters began to use their common sense and refute the increasingly putrefied political propaganda - Fake News \& lies. Recent data on fake-news is alarming. Guyana has to revive alliance between democracy and the nation-state that has come unstuck due to globalization: the increased extent, velocity, and scope of cross-border interactions, transactions, and relations. Global democracy is undermining national democracy as decisions are taken outside the state, national leaders are unable to control the forces which impact domestic institutions and citizens. Lack of control over nation's fiscal policy subverts their ability to develop and undermines national democracy. We need to eliminate the "global democratic deficit", and diminish the inimical dominating role of the World Bank, IMF, and WTO - these global undemocratic extractive institutions - have a track record of impoverishing the LAC and African nations. Privatisation is not the solution for every problem.

Globally, the digital revolution is in full force but Guyanese public and private sector leaders are stymied; and fall well behind other digital pioneers as they are yet to maximize the full potential of digital technology and big-data. Guyana for the last five decades is in the grasp of 
"analogue generation" - stuck in this rut, it has deprived itself of advancement. $21^{\text {st }}$ century belongs to young minds that reject race-based destructive politics. It is time that "netizens" and "digital generation" - the largest group, is allowed to fully participate and play a decisive role in Guyana's politics and development. Guyanese must use technology to rediscover what democracy should be for the modern nation state: citizens participating personally in public debate and having meaningful say in policy decisions that affect them - without the distorting and corruptible role of legislative proxies or elitist agency officials. We must eradicate "Political Clientelism" defined by Stokes, et al., as the exchange of goods and services for political support. Clientelist strategies are most effective in societies with a prevalence of poverty, when the cost of giving constituents gifts is low - Guyanese kleptocrat-politicians are practicing it [87,88]. To defend - and keep alive-democracy today, we need a revolution: go back to what the ancient Athenians invented in the $5^{\text {th }}$ century BCE, where every citizen regularly participated in discussion and voting for the laws that would steer their livelihoods and survival. New technology and communication tools can now provide the means to scale up for millions of people what ancient Athenians did with perhaps (at most) 50,000 citizens.

Guyana GECOM has disclosed that some 15 political parties are likely to contest the upcoming General and Regional Elections, which has been set for March 2nd, 2020. Apart from the two major parties, the People's Progressive Party/Civic (PPP/C) and the APNU/AFC coalition, there are at least five other new and small parties which have been recently launched. These include: A New and United Party (ANUG), Federal United Party (FED UP), Liberty and Justice Party (LJP), Citizenship Initiative (CI) and more recently, Change Guyana. LJP's founder and presidential candidate is Lenox Shuman. He descends from a long line of Chiefs of the Arawak's of St. Cuthbert's Mission (renamed "Pakuri") that predates the formation of Guyana. Known as the Jaguar People, the Arawak (also known as Lokono) have been known to occupy the coastal regions of South America and the Caribbean Islands and has its roots in the Indigenous identity of Guyana dating back over 30,000 years. Lenox, successfully contested the Chieftaincy of his community in July of 2015 and was also elected as Vice Chairman of the National Toshaos Council in 2015, to serve for three years. Lenox's participation in political process would contribute positively to the participative democracy and inclusive governance in Guyana. LJP's Manifesto [89] for 2020 elections is very futuristic, yet realistic and doable, road-map for Guyana's Equitable Development and Environmental Justice. The Manifesto is in two parts; Urgent Tasks - Crucial Six-Month Plan; and Five-Year Transformative Programs. The items under Crucial Six-Month Plan are those national imperative issues on which LJP would intercede immediately - on assuming office. The Five-Year Programs contain proposals for the Inclusive Sustainable Development of Guyanese and Guyana. It is a visionary strategy that will transform Guyana and bring "Prosperity" to all Guyanese. Lenox's presidential candidacy for Guyana is a good sign - this is a historic moment, long overdue. Guyanese must restore the "degenerated democracy", hacked and highjacked since independence - time to act is NOW, starting with the constitutional reforms. A satirical Cartoon by Paul Harris in the Nov. $17^{\text {th }}$ 2019 issue of The Daily Stabroek News, realistically depicts how the two main political parties have desecrated the Guyana constitution for the last 53-years [90]. One of the penalties for refusing to participate in politics is that you end up being governed by your inferiors [Plato (423 BC-347 BC)].

\section{References}

Sachs, J. 2011. The Price of Civilization. New York: Random House. ISBN 978-1-4000-6841-8. Retrieved on Nov. $5^{\text {th }}$ 2019 from: http://www.thejei.com/wp-content/uploads/2014/12/252-824-1-PB.pdf

Collier, P. 2011. The Plundered Planet: Why We Must-And How We Can-Manage Nature for Global Prosperity Oxford University Press, Oxford, UK, 2010. Retrieved on Nov.11 th 2019 from:

https://www.sid-israel.org/en/Development-Issues/What-is-Development 
Max-Neef, M. A. (1992) "From the Outside Looking In: Experiences in Barefoot Economics” Dag Hammarskjöld Foundation", pp. 208. ISBN 1-85649-188-9. Retrieved on April 12 2018 from: http://www.daghammarskjold.se/publication/outside-looking-experiences-barefoot-economics/

Fioramonti, L. (2013) Gross Domestic Problem - The Politics behind the world's most powerful number, Zed books London - New York - 2013

Loewen, W. J., 2018, "Lies My Teacher Told Me: Everything Your American History Textbook Got Wrong”, Retrieved on $4^{\text {th }}$ November 2019 from: https://4.files.edl.io/0ec3/06/28/18/155729-1b8ab639-28ff-4b2d-858e$\underline{\text { 4ecf1f9cbbc4.pdf }}$

New Internationalist, December 1991 Issue, The Stolen Continent. Retrieved on $3^{\text {rd }}$ November 2019 from: https://newint.org/features/1991/12/05/simply

Newcomb, S. 1992. Five Hundred Years of Injustice: The Legacy of Fifteenth Century Religious Prejudice. Retrieved on October 24th 2019 from: http://ili.nativeweb.org/sdrm art.html

Newcomb, S. 1992. Five Hundred Years of Injustice: The Legacy of Fifteenth Century Religious Prejudice. Retrieved on October 24th 2019 from: http://ili.nativeweb.org/sdrm art.html

Blum, W. 2006. Rogue State: A Guide to the World's Only Superpower, Zed Books Ltd. UK. ISBN 1-84277-827-7. Retrieved reference on Nov $13^{\text {th }} 2019$ from:

https://en.wikipedia.org/wiki/Rogue State: A Guide to the World\%27s Only Superpower

Newkirk, P. 2015. 'Spectacle': The Story of Ota Benga, June 3rd , 2015, available at: https://www.amazon.ca/Spectacle-Astonishing-Life-Ota-Benga/dp/0062201026

Révauger, Cécile (October 2008). The Abolition of Slavery - The British Debate 1787-1840. Presse Universitaire de France. ISBN 978-2-13-057110-0. Retrieved on Nov. 5th 2019 from:

https://www.puf.com/content/Abolition_Slavery_British_Debate_1787-1840

Infoplease, 2019. Retrieved on Nov. $9^{\text {th }} 2019$ from:

https://www.infoplease.com/world/countries/guyana/history

Fraser, C. 2000. "The 'New Frontier' of Empire in the Caribbean: The Transfer of Power in British Guiana, 19611964". International History Review 22, no.3 (September 2000): 583-610. RG059/LBJ Library/JRF Library. Retrieved on Nov. $5^{\text {th }} 2019$ from: https://www.tandfonline.com/doi/abs/10.1080/07075332.2000.9640910

Burgis, T. 2016. The Looting Machine: Warlords, Oligarchs, Corporations, Smugglers, and the Theft of Africa's Wealth. Public Affairs, NY. Available at:

https://kissly.net/book/E0B22F7911687F794CCF?utm_source=ps79\&utm_medium=nimezusyjyru.cf\&utm_camp aign $=$ fnom $\& \mathrm{x}=977486$

Blum, W. 2013. America's Deadliest Export: Democracy - the Truth about US Foreign Policy and Everything Else, 2013, Zed Books Ltd, London, UK, and NY USA. Retrieved on Nov. 13 2019 from: www.zedbooks.co.uk

Perkins, J. 2016. Confessions of an Economic Hit Man, Publisher: Berrett-Koehler Publishers; $2^{\text {nd }}$ edition

Burgis, T. 2016. The Looting Machine: Warlords, Oligarchs, Corporations, Smugglers, and the Theft of Africa's Wealth. Public Affairs, NY. Available at:

https://kissly.net/book/E0B22F7911687F794CCF?utm source=ps79\&utm medium=nimezusyiyru.cf\&utm camp aign $=$ fnom $\& \mathrm{x}=977486$

Loewen, W. J., 2018, “Lies My Teacher Told Me: Everything Your American History Textbook Got Wrong”, Retrieved on $4^{\text {th }}$ November 2019 from: https://4.files.edl.io/0ec3/06/28/18/155729-1b8ab639-28ff-4b2d-858e4ecf1f9cbbc4.pdf

Burgis, T. 2016. The Looting Machine: Warlords, Oligarchs, Corporations, Smugglers, and the Theft of Africa's Wealth. Public Affairs, NY. Available at:

https://kissly.net/book/E0B22F7911687F794CCF?utm_source=ps79\&utm_medium=nimezusyjyru.cf\&utm_camp aign $=$ fnom $\& \mathrm{x}=977486$

BBC-YouTube, 2017, BBC full documentary, The Empire Pays Back. Available on YouTube at: https://www.youtube.com/watch?v=MzctBXOHewk\&t=4s

Beckford, R. 2005. The Empire Pays Back, A BBC documentary, first aired in 2005. Retrieved on Nov. $9^{\text {th }} 2019$ from: http://thevincentian.com/the-empire-pays-back-p3650-110.htm

Fanon, F. 1961, THE WRETCHED OF THE EARTH, Grove Weidenfeld A division of Grove Press, Inc. NewYork, NY. Originally published by François Maspero éditeur, Paris, France, under the title Les damnés de la terre. 
Fanon, F. 1961, THE WRETCHED OF THE EARTH, Grove Weidenfeld A division of Grove Press, Inc. NewYork, NY. Originally published by François Maspero éditeur, Paris, France, under the title Les damnés de la terre.

Fairchild, 2010, Retrieved on Nov. 5th 2019 from: https://en.wikipedia.org/wiki/The Wretched of the Earth

Burgis, T. 2016. The Looting Machine: Warlords, Oligarchs, Corporations, Smugglers, and the Theft of Africa's Wealth. Public Affairs, NY. Available at:

https://kissly.net/book/E0B22F7911687F794CCF?utm_source=ps79\&utm medium=nimezusyjyru.cf\&utm camp aign $=$ fnom $\& \mathrm{x}=977486$

Kelman, H. C. (1976). "Violence without restraint: Reflections on the dehumanization of victims and victimizers". pp. 282-314 in G. M. Kren \& L. H. Rappoport (Eds.), Varieties of Psychohistory. New York: Springer. ISBN 0826119409. Retrieved on Nov 15 2019 from: https://en.wikipedia.org/wiki/Dehumanization

Louw, D. J. 2014. Verbum et Ecclesia, On-line version, vol.35 n.2 Pretoria, 2014. ISSN 2074-7705. Retrieved on Nov $15^{\text {th }} 2019$ from: http://www.scielo.org.za/scielo.php?script=sci arttext\&pid=S2074-77052014000200010

Paulo Freire, 2000, Pedagogy of Freedom-Ethics Democracy and Civic Courage-2000. Retrieved on Nov. 15 2019 from: http://abahlali.org/wp-content/uploads/2012/08/Paulo-Freire-Pedagogy-of-Freedom-Ethics-Democracyand-Civic-Courage-2000.pdf

Fuchs, T. 2013. Karl Jasper's Philosophy and Psychopathology (2013), Retrieved on Nov. 15 2019 from: https://www.researchgate.net/publication/298650565 Karl Jaspers' Philosophy and Psychopathology Acemoglu, D., and Robinson, J. A., 2012, “The Origins of Power, Prosperity and Poverty - Why Nations Fail”, retrieved on Nov. $10^{\text {th }} 2019$ from: http://whynationsfail.com/

Rodney, W. 1973. How Europe Underdeveloped Africa, Published by: Bogle-L'Ouverture Publications, London and Tanzanian Publishing House, Dar-Es-Salaam 1973, Republished 2018

Brass, T. 2004. Hamza Alavi (1921-2003) Journal of Peasant Studies, 1743-9361, Volume 31, Issue 2, Pages 341 344

USAID Final Report 2016 - Democracy Human Rights and Governance Assessment of Guyana. Retrieved on Nov. $5^{\text {th }} 2019$ from: https://photos.state.gov/libraries/guyana/19452/pdfs/Final-Guyana-DRG-Assessment-PublicVersion-March-2016.pdf

Ipsos, 2019, Global trust in professions - Who do global citizens trust? Retrieved on Nov. $9^{\text {th }} 2019$ from: https://www.ipsos.com/sites/default/files/ct/news/documents/2019-09/global-trust-in-professions-trustworthiness-index-2019.pdf

Plato, 350BC, The Republic, English Translation by Shorey, P. II Books Vi-X, Harvard University Press, MA-USA

Kuehnelt-Leddihn, 1988. Democracy's Road to Tyranny. Retrieved on Nov. $5^{\text {th }} 2019$ from:

https://fee.org/articles/democracys-road-to-tyranny/

Tocqueville, Alexis de (2003). Democracy in America and Two Essays on America, Penguin Classics, $13^{\text {th }}$ printing Edition. Retrieved on Nov. $5^{\text {th }} 2019$ from: https://academyofideas.com/2016/12/democracy-road-to-tyranny/

Kuehnelt-Leddihn, 1988. Democracy's Road to Tyranny. Retrieved on Nov. $5^{\text {th }} 2019$ from: https://fee.org/articles/democracys-road-to-tyranny/

Kuehnelt-Leddihn, 1988. Democracy's Road to Tyranny. Retrieved on Nov. $5^{\text {th }} 2019$ from: https://fee.org/articles/democracys-road-to-tyranny/

Bullough, 0., 2019, Moneyland: The Inside Story of the Crooks and Kleptocrats Who Rule the World, May 7, 2019 by Oliver Bullough, https://www.theguardian.com/books/2018/sep/09/moneyland-oliver-bullough-reviewwealth-corruption-oligarchs

Burgis, T. 2016. The Looting Machine: Warlords, Oligarchs, Corporations, Smugglers, and the Theft of Africa's Wealth. Public Affairs, NY. Available at:

https://kissly.net/book/E0B22F7911687F794CCF?utm source=ps79\&utm medium=nimezusyjyru.cf\&utm camp aign $=$ fnom $\& \mathrm{x}=977486$

Foer, F. 2019, Russian-Style Kleptocracy Is Infiltrating America, POLITICS, March 2019 Issue, retrieved on Oct. 24th 2019 from: https://www.theatlantic.com/magazine/archive/2019/03/how-kleptocracy-came-toamerica/580471/ 
Soll, J. 2016. The Long and Brutal History of Fake News, POLITICO Magazine, 18-Dec-2016. [Online]. Available: http://politi.co/2FaV5W9. Retrieved Nov. $5^{\text {th }} 2019$ from: https://www.politico.com/magazine/story/2016/12/fake-news-history-long-violent-214535

Rado, M. and Fagoaga, J. 2019. True information, a luxury in the $21^{\text {st }}$ century. Retrieved on November $5^{\text {th }} 2019$ from: https://blog.ferrovial.com/en/2019/02/true-information/

Womack, J. 2012. Capitalism: Servant or Master, Soliloquy Press (8 July 2012). Available at: https://www.amazon.co.uk/John-Womack/e/B001K91G6W

Sachs, J. 2011. The Price of Civilization. New York: Random House. ISBN 978-1-4000-6841-8. Retrieved on Nov. $5^{\text {th }}$ 2019 from: http://www.thejei.com/wp-content/uploads/2014/12/252-824-1-PB.pdf

Schlozman et al., (2017) Growing Economic Inequality and Its (Partially) Political Roots, Religions 2017, 8, 97; doi:10.3390/rel8050097 www.mdpi.com/journal/religions

Atkinson, A. 2015. Inequality: What Can Be Done? Cambridge: Harvard University Press.

Piketty, T. 2014. Capital in the Twenty-First Century. Cambridge: Harvard University Press.

Lioz, M. 2014. More Than Corruption Threatens the Integrity of Our Democracy. The sad tale of how the Supreme Court got McCutcheon v. FEC wrong and how that's helping to foster an Inequality Era. Available at: https://prospect.org/power/corruption-threatens-integrity-democracy/

Sachs, J. 2011. The Price of Civilization. New York: Random House. ISBN 978-1-4000-6841-8. Retrieved on Nov. $5^{\text {th }}$ 2019 from: http://www.thejei.com/wp-content/uploads/2014/12/252-824-1-PB.pdf

Bullough, O., 2019, Moneyland: The Inside Story of the Crooks and Kleptocrats Who Rule the World, May 7, 2019 by Oliver Bullough, https://www.theguardian.com/books/2018/sep/09/moneyland-oliver-bullough-reviewwealth-corruption-oligarchs

Bullough, 0., 2019, Moneyland: The Inside Story of the Crooks and Kleptocrats Who Rule the World, May 7, 2019 by Oliver Bullough, https://www.theguardian.com/books/2018/sep/09/moneyland-oliver-bullough-reviewwealth-corruption-oligarchs

Bullough, 0., 2019, Moneyland: The Inside Story of the Crooks and Kleptocrats Who Rule the World, May 7, 2019. Retrieved on Nov. $10^{\text {th }} 2019$ from: https://www.theguardian.com/books/2018/sep/09/moneyland-oliverbullough-review-wealth-corruption-oligarchs

Medina, J. 2014. Brain Rules - 12 Principles for Surviving and Thriving at Work, Home, and School, Pear Press. Retrieved on Nov. 5 2019 from: https://facultylibrary.dmcodyssey.org/wp-content/uploads/2016/11/BrainRules-by-John-Medina.pdf

Giroux, H. A. 2014. America's Education Deficit and the War on Youth, Monthly Review Press, New York. Retrieved on Nov. 10 2019 from: https://monthlyreview.org/product/americas education deficit and the war on youth/

The World's Women 2015 Report - Trends and Statistics. Retrieved on October $30^{\text {th }} 2019$ from: https://unstats.un.org/unsd/gender/downloads/worldswomen2015_report.pdf

Smith, R. H. 1920. Justice and the Poor. Source: Political Science Quarterly, Vol. 35, No. 1 (Mar., 1920), pp. 152154, Published by: The Academy of Political Science. Retrieved on Nov. $10^{\text {th }} 2019$ from:

https://www.questia.com/library/120087978/america-s-education-deficit-and-the-war-on-youth

Rule of Law Index 2019- World Justice Project 2018-2019. Retrieved on Nov. $5^{\text {th }} 2019$ from: https://worldjusticeproject.org/sites/default/files/documents/ROLI-2019-Reduced.pdf

Tenove et al. 2018. Digital Threats to Democratic Elections, Research Report, Center for the Study of Democratic Institutions, University of British Columbia, Canada. Retrieved on October 30 2019 from: https://papers.ssrn.com/sol3/papers.cfm?abstract id=3235819

Tenove et al. 2018. Digital Threats to Democratic Elections, Research Report, Center for the Study of Democratic Institutions, University of British Columbia, Canada. Retrieved on October 30 2019 from:

https://papers.ssrn.com/sol3/papers.cfm?abstract id=3235819

Cadwalladr, C. 2017. The great British Brexit robbery: how our democracy was hijacked, The Guardian May 7th 2017. Retrieved on Nov. $5^{\text {th }} 2019$ from: https://www.theguardian.com/technology/2017/may/07/the-greatbritish-brexit-robbery-hijacked-democracy

Tenove et al. 2018. Digital Threats to Democratic Elections, Research Report, Center for the Study of Democratic Institutions, University of British Columbia, Canada. Retrieved on October 30 2019 from: https://papers.ssrn.com/sol3/papers.cfm?abstract id=3235819 
Engelhardt, T. 2014. Shadow Government: Surveillance, Secret Wars, and a Global Security State in a Single Superpower World. Chicago: Haymarket Books. ISBN 9781608464272. Available at:

https://www.dailymotion.com/video/x4v9cfe

Marlowe, A. 2018. How Cambridge Analytica fueled a shady global passport bonanza. FastCompany. Retrieved on October 30 2019 from: https://www.fastcompany.com/40571052/how-cambridge-analytica-fueled-a-shadyglobal-passport-bonanza

Witt, J. and Pasternack, A. 2019. Before Trump, Cambridge Analytica's parent built weapons for war, FastCompany, Retrieved on October 30 2019 from: https://www.fastcompany.com/90235437/before-trumpcambridge-analytica-parent-built-weapons-for-war

Fuller, R. 2019. In Defence of Democracy ISBN: 978-1-509-53313-8, Wiley Publishers. September 2019. Available at: https://lib.ugent.be/en/catalog/rug01:002774209

Clarke, M. 2012. The Digital Revolution, Academic and Professional Publishing, 2012. Retrieved on Nov. $6^{\text {th }} 2019$ from: https://www.sciencedirect.com/topics/psychology/digital-revolution

Baluch, et al., 2013. Impelling Innovation at a Canadian Automotive Plant, Innovative Systems Design and Engineering, www.iiste.org, ISSN 2222-1727 (Paper) ISSN 2222-2871 (Online) Vol.4, No.3, 2013. Available at: https://scholar.google.com/citations?user=S8UiSAYAAAA/\&hl=en

Freedom in the World Annual Report, 2019. Retrieved on Nov. $6^{\text {th }} 2019$ from: https://freedomhouse.org/sites/default/files/Feb2019 FH_FITW_2019 Report_ForWeb-compressed.pdf

Scholte, J. A. 2014. Reinventing Global Democracy, European Journal of International Relations, 20(1): 3-28. Retrieved on October 30th 2019 from: https://journals.sagepub.com/doi/full/10.1177/1354066111436237

Zürn, M., Binder, M., \& Ecker-Ehrhardt, M. 2012. International Authority and its Politicization, International Theory, 4(1): 69-106. Retrieved on Nov. $5^{\text {th }} 2019$ from:

https://www.researchgate.net/publication/232001293 International Political Authority and Its Politicization

Agné, H. 2006. A dogma of democratic theory and globalization: why politics need not include everyone it affects, European Journal of International Relations, 12(3): 433-458. Retrieved on October 30 2019 from: https://journals.sagepub.com/doi/abs/10.1177/1354066106067350

Acemoglu, D., and Robinson, J. A., 2012, "The Origins of Power, Prosperity and Poverty - Why Nations Fail", retrieved on Nov. 10 2019 from: http://whynationsfail.com/

Cavanagh, J. and Mander, J. 2007. A CRITIQUE OF CORPORATE GLOBALIZATION, 2007 (PART III): World Bank, IMF turned poor Third World nations into loan addicts, retrieved on Nov. $6^{\text {th }} 2019$ from:

https://www.tru.ca/library/pdf/cavanagh-mander.pdf

Blum, W. 2006. Rogue State: A Guide to the World's Only Superpower, Zed Books Ltd. UK. ISBN 1-84277-827-7. Retrieved reference on Nov $13^{\text {th }} 2019$ from:

https://en.wikipedia.org/wiki/Rogue State: A Guide to the World\%27s Only Superpower

WW-Bulletin, 2019, US-backed coup deposes Evo Morales in Bolivia, Workers' World Bulletin News, Nov 10 th 2019, retrieved on Nov 13 ${ }^{\text {th }} 2019$ from: https://www.workers.org/2019/11/44357/

Blum, W. 2013. America's Deadliest Export: Democracy - the Truth about US Foreign Policy and Everything Else, 2013, Zed Books Ltd, London, UK, and NY USA. Retrieved on Nov. 13 2019 from: www.zedbooks.co.uk

DW, 2019, Bolivia scraps joint lithium project with German firm ACISA, DW News Nov $4^{\text {th }} 2019$, retrieved on Nov $13^{\text {th }} 2019$ from: https://www.dw.com/en/bolivia-scraps-joint-lithium-project-with-german-company/a$\underline{51100873}$

Paulo Freire, 2000, Pedagogy of Freedom-Ethics Democracy and Civic Courage-2000. Retrieved on Nov. 15 2019 from: http://abahlali.org/wp-content/uploads/2012/08/Paulo-Freire-Pedagogy-of-Freedom-Ethics-Democracyand-Civic-Courage-2000.pdf

Baluch \& Rambarran, 2018, Exigency of Infrastructure for Developing Hinterland Communities of Guyana, Paper presented at the "Inaugural Entrepreneurship \& Innovation Conference", School of Entrepreneurship and Business Innovation, University of Guyana; held on 20-22 May 2018 at the Ramada Georgetown Princess Hotel Guyana. Available at: https://scholar.google.com/citations?user=S8UiSAYAAAAJ\&hl=en

Baluch, N. 2013, Coconut Biofuel and the role of Maintenance Technology Management in Sustaining Coastal Rural Communities: Contextualizing Exigency of "Almond Beach Community" in Guyana. Paper Presented at Australian 
Association for Caribbean Studies, La Trobe University, Australia. Retrieved on Nov 16th 2019 from:

https://scholar.google.com/citations?user=S8UiSAYAAAAJ\&hl=en

Abdullah et al., 2015 Abdullah, CS., Baluch, N., Mohtar, S. 2015. Ascendancy of Ultrasonic Reactor for Micro Biodiesel Production, Jurnal Teknologi, Vol 5, Issue 7, pp 155-161. 2015. Retrieved on Nov 16th 2019 from: https://scholar.google.com/citations?user=S8UiSAYAAAAJ\&hl=en

Baluch, N. 2014, Bio-WRAP Model: Propitious Green Power \& Transport Theorem for Guyana. Paper presented at World Renewable Energy Congress (WREC, 2013) Murdoch University, Perth, Australia. Retrieved on Nov 16th 2019 from: https://scholar.google.com/citations?user=S8UiSAYAAAAJ\&hl=en

Baluch \& Rambarran, 2018, Green Social Entrepreneurship: Evaluating Micro Ultrasonic Biodiesel Production in Guyana, Paper presented at University of Guyana; Faculty of Social Sciences - Turkeyen Campus, Inaugural Research Day Conference held on September 4th, 2018. Available at: https://scholar.google.com/citations?user=S8UiSAYAAAA/\&hl=en

Baluch \& Rambarran, 2019, Understanding Local Content Policy in Guyana's Oil \& Gas Sector: A Critical Overview, paper submitted to University of Guyana: School of Entrepreneurship and Business Innovation Guyana Diaspora and Entrepreneurship Conference, July 2019, at Turkeyen Campus, Georgetown, Guyana. Available at: https://scholar.google.com/citations?user=S8UiSAYAAAAJ\&hl=en

Stokes, S. C., Dunning, T., Nazareno, M., Brusco, V. 2013. Brokers, Voters, and Clientelism: The Puzzle of Distributive Politics. ISBN 978-1107660397. Available at:

https://sites.lsa.umich.edu/webbkeane/wpcontent/uploads/sites/223/2015/01/stokes dunning_nazareno and brusco um.pdf

Kramon, E. 2017. "Money for Votes: The Causes and Consequences of Electoral Clientelism in Africa". Cambridge Core. Retrieved on Nov 14th 2019 from:

https://www.researchgate.net/publication/333060833 Money for Votes The Causes and Consequences of Elec toral Clientelism in Africa By Eric Kramon Cambridge Cambridge University Press 2017 244p 9999 cloth

Liberty and Justice Party Manifesto - 2020 elections. Available at: http://voteljp.com/

Satirical Cartoon by Paul Harris in The Daily Stabroek News - Nov. 17th 2019 issue. Accessible online at:

https://www.stabroeknews.com/2019/11/17/opinion/cartoon/cartoons-139/

\section{AUTHOR \\ Dr. Nazim Baluch \\ nazimbaluch@gmail.com \\ Publications Link: https://scholar.google.com/citations?user=S8UiSAYAAAAI\&hl=en}

Dr Nazim Baluch, a Canadian, served as an academic at Universiti Utara Malaysia for five years, till 2017. He went to Mohawk College of Applied Arts and Technology (a degree granting institution) and McMaster University, Hamilton, Ontario, Canada for his under graduate studies specializing in Mechanical \& Maintenance Engineering Technology and Automation in Manufacturing. He obtained his MBA in 2004 from University of Guelph, Ontario, Canada and $\mathrm{PhD}$ in Technology Management from Universiti Utara Malaysia (AACSB accredited Institution) in 2012. Prior to joining academia, he worked in the Canadian Automotive Industry, Magna International, and Supply Chain Management (warehousing) with hands on experience in 'Manufacturing and Operations Management'. He has authored over 63 academic Journal articles and Conference papers and five books. His areas of specialization include: Operations \& Technology Management for sustainable global supply and value chains; Maintenance Engineering Technology \& Management; Innovative Process Improvement; Renewable Sources of Energy; Appropriate Technologies and Management Practices for Sustainable Inclusive Development; Green Social Entrepreneurship, and Knowledge Transfer - University, Industry, Community and Government Collaboration. 